\title{
Long-term effects of adjuvant tamoxifen treatment on cardiovascular disease and cancer
}

\author{
Johan Rosell
}

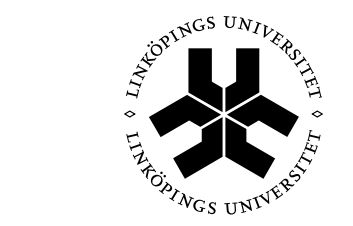

Linköping University

FACULTY OF HEALTH SCIENCES

Linköping University, Faculty of Health Sciences

Department of Clinical and Experimental Medicine,

Division of Clinical Sciences, Oncology

SE-581 85 Linköping, Sweden 
ISBN: 978-91-7519-182-9

ISSN: 0345-0082

Printed by LiU-Tryck, Linköping 2014 


\begin{abstract}
The aims of this thesis were to investigate the long-term effects of adjuvant tamoxifen treatment on breast cancer recurrence and mortality, cardiovascular disease, and the incidence of secondary cancer.

Between 1982 and 1992, postmenopausal patients with early stage breast cancer were included in a randomized clinical study of 2 or 5 years of postoperative tamoxifen therapy. The trial was planned by the Swedish Breast Cancer Group, and it included 4610 patients. Follow-up on causes of death, hospitalizations and secondary cancers were obtained from national population-based registries.

All-cause mortality, breast cancer-specific mortality and mortality from coronary heart disease were decreased in the 5-year group, but the incidence of endometrial cancer was increased (Paper I). The incidence and mortality of cerebrovascular diseases were increased during the active treatment phase, and reduced after the active treatment (Paper II). Similar results were seen for subgroups of cerebrovascular diseases such as stroke and ischemic stroke. In the 5-year group, the morbidity from coronary heart disease was reduced during treatment but not after treatment was stopped (Paper III). This was the case also for heart failure and for atrial fibrillation/flutter. For secondary cancers the lung cancer risk was reduced, as well as the lung cancer mortality (Paper IV). An increased risk was observed for endometrial cancer, but appeared to decrease over time. The risk of contralateral breast cancer was reduced, with most of the reduction after treatment was stopped. For distance recurrences the risk was reduced both during treatment and a few years after treatment was stopped. The breast cancer mortality was also reduced, especially during the post-treatment phase.
\end{abstract}

Key words: Adjuvant treatment; Adverse events; Breast cancer; Cerebrovascular disease; Coronary heart disease; Heart failure; Lung cancer; Second primary cancer; Tamoxifen 



\section{List of papers}

This thesis is based on the following papers, which will be referred to in the text by their Roman numerals:

I. Nordenskjöld B, Rosell J, Rutqvist LE, Malmström PO, Bergh J, Bengtsson NO, Hatschek T, Wallgren A, Carstensen J. Coronary heart disease mortality after 5 years of adjuvant tamoxifen therapy: results from a randomized trial.

J Natl Cancer Inst 2005;97:1609-1610.

II. Rosell J, Nordenskjöld B, Bengtsson NO, Fornander T, Hatschek T, Lindman H, Malmström PO, Wallgren A, Stål O, Carstensen J. Time dependent effects of adjuvant tamoxifen therapy on cerebrovascular disease: results from a randomised trial. Br J Cancer 2011;104:899-902.

III. Rosell J, Nordenskjöld B, Bengtsson NO, Fornander T, Hatschek T, Lindman H, Malmström PO, Wallgren A, Stål O, Carstensen J. Effects of adjuvant tamoxifen therapy on cardiac disease: results from a randomized trial with long-term follow-up. Breast Cancer Res Treat 2013;138:467-473.

IV. Rosell J, Nordenskjöld B, Bengtsson NO, Fornander T, Hatschek T, Lindman H, Malmström PO, Wallgren A, Stål O, Carstensen J. Effects of adjuvant tamoxifen therapy on the incidence of secondary cancer: results from a randomized trial with long term follow-up.

Submitted.

Paper I was reprinted with permission from Oxford University Press. Paper II was reprinted with permission from Nature Publishing Group. Paper III is published with permission from the copyright holder. 



\section{Table of contents}

$\begin{array}{lr}\text { Abbrevations } & \mathbf{1} \\ \text { Introduction } & \mathbf{3} \\ \text { Breast cancer } & 3 \\ \text { Causes of death } & 4 \\ \text { Adjuvant tamoxifen treatment } & 5\end{array}$

Side effects of tamoxifen $\quad 5$

Blood lipids and C-reactive protein $\quad 5$

$\begin{array}{ll}\text { Coronary heart disease } & 6\end{array}$

$\begin{array}{ll}\text { Cerebrovascular disease } & 6\end{array}$

$\begin{array}{ll}\text { Secondary cancer } & 6\end{array}$

$\begin{array}{ll}\text { Aims of the present thesis } & 7\end{array}$

$\begin{array}{lr}\text { Patients and methods } & 9\end{array}$

$\begin{array}{ll}\text { Patients in Papers I-IV } & 9\end{array}$

$\begin{array}{ll}\text { Data sources } & 10\end{array}$

$\begin{array}{ll}\text { The Hospital Discharge Registry } & 10\end{array}$

$\begin{array}{ll}\text { The Causes of Death Registry } & 11\end{array}$

$\begin{array}{ll}\text { The Cancer Registry } & 11\end{array}$

$\begin{array}{ll}\text { Statistical methods } & 11\end{array}$

$\begin{array}{ll}\text { Results } & 13\end{array}$

$\begin{array}{ll}\text { Paper I } & 13\end{array}$

$\begin{array}{lr}\text { Paper II } & 15\end{array}$

$\begin{array}{lr}\text { Paper III } & 18\end{array}$

$\begin{array}{ll}\text { Paper IV } & 21\end{array}$ 
$\begin{array}{lr}\text { Discussion of results } & 29\end{array}$

$\begin{array}{ll}\text { Cardiovascular disease } & 29\end{array}$

$\begin{array}{ll}\text { Cancer } & 30\end{array}$

Discussion of methods

$\begin{array}{ll}\text { Conclusions } & 35\end{array}$

$\begin{array}{lr}\text { Acknowledgements } & 37\end{array}$

Populärvetenskaplig sammanfattning på svenska 39

$\begin{array}{ll}\text { References } & 41\end{array}$ 


\begin{tabular}{ll} 
Abbrevations \\
AE & Adverse event \\
AF & Atrial fibrillation/flutter \\
CHD & Coronary heart disease \\
CI & Confidence interval \\
CRP & C-reactive protein \\
EBCTCG & Early Breast Cancer Trialists' Collaborative Group \\
HDL & High-density lipoprotein \\
HDR & Hospital Discharge Registry \\
HF & Heart failure \\
HR & Hazard ratio \\
ICD & International Classification of Diseases \\
LDL & Low-density lipoprotein \\
MI & Myocardial infarction \\
WHO & World Health Organization \\
\hline
\end{tabular}




\section{Introduction}

\section{Breast cancer}

Breast cancer is the most common cancer in women worldwide and a leading cause of death (Figure 1) [1]. Nearly 1.7 million new cases of breast cancer were diagnosed in the world 2012. This represents about $12 \%$ of all new cancer cases and $25 \%$ of all cancers in women. The incidence is higher in industrialized countries than in most developing countries of the world. In Sweden, more than 8400 new cases were reported 2012, which constituted over $30 \%$ of all female cancer [2]. The age standardized incidence rate has increased by $1.4 \%$ annually during the last 20 years. Breast cancer mortality in contrast to breast cancer incidence has been stable since the 1960s and since the 1980s tends to decrease. In Sweden between 1987-1996 the estimated annual percent change in breast cancer mortality was $-1.2 \%$ [3], and for later years an annual reduction of $-0.6 \%$ has been reported [4].

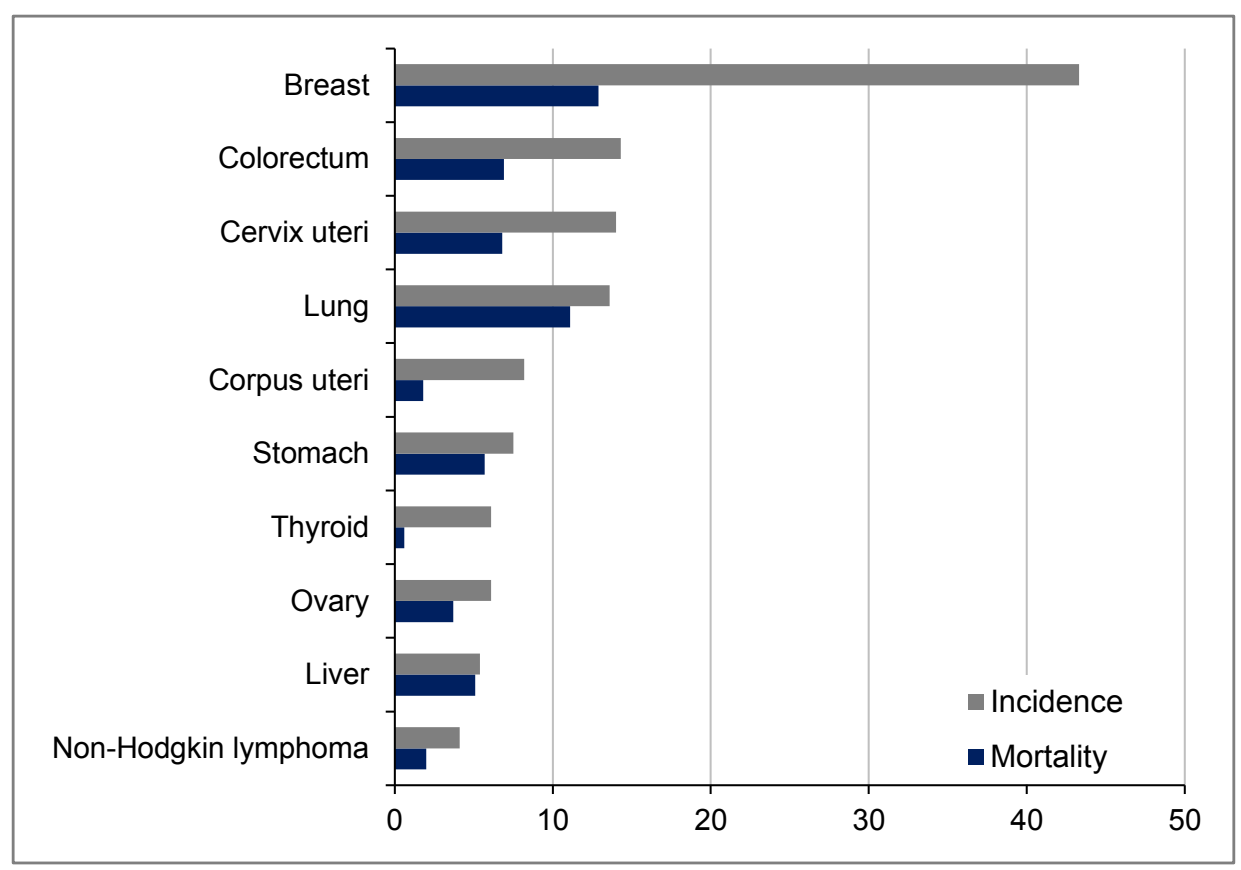

Figure 1. The ten most common cancers among women in year 2012 worldwide. Agestandardized incidence- and mortality rates (world) per 100,000. GLOBALCAN 2012, IARC. 
This improvement in survival may be explained by factors such as early detection by mammographic screening and improved treatment.

\section{Causes of death}

Less than one of three breast cancer patients dies from the disease. The most common cause of death for women in Sweden is diseases of the circulatory system, which in 2013 was the underlying cause of death in 38\% [5] (Figure 2). The second most common cause of death is neoplasms (24\%). Among neoplasms, lung cancer is the leading causes of death, and has increased substantially since the late eighties. In 2005 lung cancer surpassed breast cancer to become the most common cause of cancer death in women.

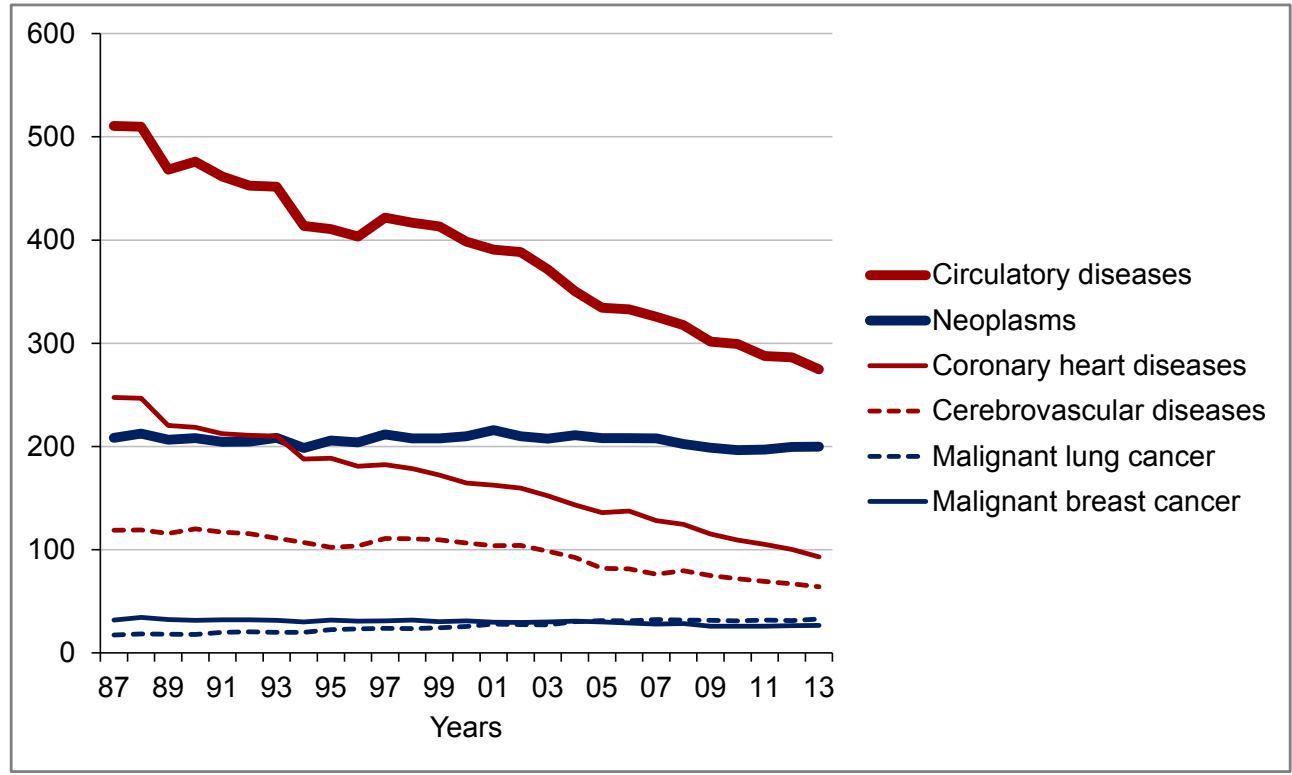

Figure 2. Age standardized mortality rates per 100,000 women in Sweden, 1987-2013. 


\section{Adjuvant tamoxifen treatment}

Tamoxifen is still a widely used breast cancer drug, and has been a very important endocrine therapy for several decades [6]. Tamoxifen is used for the treatment of both early and advanced estrogen receptor (ER)-positive breast cancer in pre- and postmenopausal patients [7]. Tamoxifen binds to ER-receptors in breast cancer cells and may stop estrogen dependent cellreplication. The first randomized trials of adjuvant tamoxifen for early stage breast cancer were initiated in the middle 1970s. Most of these trials compared 1 or 2 years of tamoxifen therapy with no adjuvant treatment. These studies showed significantly reduced disease recurrences among tamoxifen-assigned patients. It was suggested that the benefit with tamoxifen might be further increased by the use of prolonged treatment. A multicenter randomized trial was intitiated in Sweden in the early 1980s that compared 2 years with 5 years of adjuvant tamoxifen in the treatment of postmenopausal women with early stage, invasive breast cancer [8]. Results from this study and other randomized trials showed that 5 years of tamoxifen is superior to shorter duration in reductions of mortality, recurrences and contralateral breast cancer $[9,10]$.

\section{Side effects of tamoxifen}

Tamoxifen commonly causes a range of side effects such as hot flashes and sweating [11, 12] and less often more serious adverse events (AEs) such as endometrial cancer and thromboembolic events $[9,13]$. Tamoxifen is also associated with several of positive effects.

\section{Blood lipids and C-reactive protein}

There are several types of lipids in the blood, such as cholesterol. Cholesterol is carried in the blood by lipoproteins: low-density lipoprotein (LDL) and high-density lipoprotein (HDL). High levels of LDL cholesterol lead to atherosclerosis increasing the risk of heart attack and ischemic stroke. HDL cholesterol reduces the risk of cardiovascular disease as it carries cholesterol away from the blood stream. Tamoxifen appears to produce an estrogen-like effect upon the lipid profile in postmenopausal women. Its use has lipid-lowering properties by decreasing total and LDL cholesterol $[14,15]$. The reduction in total serum cholesterol levels was shown to be mainly a result of decreased levels of LDL cholesterol [14]. Furthermore, among patients treated with tamoxifen the levels of LDL cholesterol has shown to be more lowered in postmenopausal women than in premenopausal women [16], and also among healthy women with higher risk for breast cancer treated with tamoxifen as primary prophylaxis the reduction of LDL cholesterol appears to be larger in postmenopausal women [17].

Another risk factor for cardiovascular diseases is C-reactive protein (CRP), which is a general marker for inflammation and infection, and a known risk factor for cardiovascular diseases. Among women with breast cancer treated with tamoxifen reductions in CRP has been reported, especially among postmenopausal women [15]. Both CRP and LDL cholesterol levels are strong predictors of cardiovascular events. In a study with healthy women 45 years or older it was showed that CRP was a stronger predictor than LDL cholesterol levels [18]. 


\section{Coronary heart disease}

Two randomized trials of adjuvant tamoxifen therapy have reported an early benefit of tamoxifen on cardiac diseases. A Scottish study showed that the incidence of hospital admission for myocardial infarction (MI) was lower in the treatment arm of the study compared to untreated controls, and the reduction was most apparent during the first years of follow-up [19]. In another study among patients receiving 2 or 5 years of adjuvant tamoxifen, the number of first hospital admissions for MI and other ischemic heart disease were lower in the 5-year treatment arm [20]. The reduction in admissions due to any cardiac disease was statistically significant, especially during the period 2-5 years after surgery. A long-term effect of tamoxifen on coronary heart disease (CHD) has been reported by Cuzick et al. [21]. In their randomized prevention trial it was shown that during the active treatment period compared to the post-treatment phase there was a decreased risk of CHD.

\section{Cerebrovascular disease}

A meta-analysis of randomized trials found tamoxifen use to be significantly associated with increased risk of stroke [22], and it has been shown that especially ischemic stroke is increased [23]. Most of the studies have limited follow-up time and few events of cerebrovascular disease during the period after treatment was stopped. No studies have been able to report a long-term effect of tamoxifen on cerebrovascular disease.

\section{Secondary cancer}

Tamoxifen use increases the risk of endometrial cancer [10]. Less is known of the long-term effects among postmenopausal women. Cuzick et al. demonstrated in a randomized prevention trial (tamoxifen 5 years vs. placebo) among women, aged 35-70 years, that the risk of endometrial cancers were increased only during treatment period [21]. Few studies have reported the long-term effect of tamoxifen on contralateral breast cancer. However, Cuzick et al. found that the benefit of tamoxifen extended for at least 10 years [21]. 


\section{Aims of the present thesis}

\section{Paper I}

To study mortality as well as cancer incidence in the 2-year group and 5-year group of adjuvant tamoxifen treatment.

\section{Paper II}

To study effects of tamoxifen both during and after treatment on cerebrovascular disease and cerebrovascular mortality.

\section{Paper III}

To study long-term effects of tamoxifen on cardiac disease and cardiac mortality.

\section{Paper IV}

To study long-term effects of tamoxifen on second primary cancer incidence and mortality. 


\section{Patients and methods}

\section{Patients in Papers I-IV}

From 1982 through 1992, a total of 4610 postmenopausal patients less than 75 years of age with operable, axillary lymph node-negative or -positive, invasive breast cancer entered the trial. Primary surgery consisted of either modified radical mastectomy or breast-conserving surgery. Radiation therapy was indicated for patients with lymph-node-positive disease and was generally offered to all women who were treated with breast-conserving surgery. They were randomized to receive either 2 years or 5 years of adjuvant tamoxifen. The patients were included from five of six Swedish health care regions (South Sweden, South-East Sweden, Stockholm, Uppsala-Örebro and North Sweden); two of which used 20-mg daily doses of tamoxifen and three of which used 40-mg daily doses of tamoxifen (Table 1).

Table 1. Study characteristics by trial center.

\begin{tabular}{lclcc}
\hline Trial center & $\begin{array}{c}\text { Randomly } \\
\text { assigned }\end{array}$ & $\begin{array}{c}\text { Stage at } \\
\text { diagnosis }\end{array}$ & $\begin{array}{c}\text { Estrogen } \\
\text { receptor status }\end{array}$ & $\begin{array}{c}\text { Daily tamoxifen } \\
\text { dose, mg }\end{array}$ \\
\hline South Sweden & 1320 & II & Any & 20 \\
South-East Sweden, stage I* & 524 & I & Positive & 40 \\
South-East Sweden, stage II-IIIA & 1167 & II-IIIA & Any & 40 \\
Stockholm & 811 & I-IIIA & Any & 40 \\
Uppsala-Örebro & 583 & II & Any & 20 \\
North Sweden & 205 & Node positive & Any & 40 \\
\hline
\end{tabular}

${ }^{*}$ ER-positive only.

In Paper I, a total of 4175 patients who remained alive and breast cancer recurrence free at 2 years since start of treatment, and could thus contribute meaningful information to the comparison of outcomes associated with 2 years of tamoxifen treatment and with 5 years of tamoxifen treatment, were included in the analysis. The patients were followed up until December 31, 2000. In Papers II-III, a total of 4150 patients were included in analysis, and were followed until December 31, 2003. In Paper IV, a total of 4128 patients were included in analysis with follow-up until December 31, 2009. Figure 3 shows a flow on all patients in Papers I-IV. 


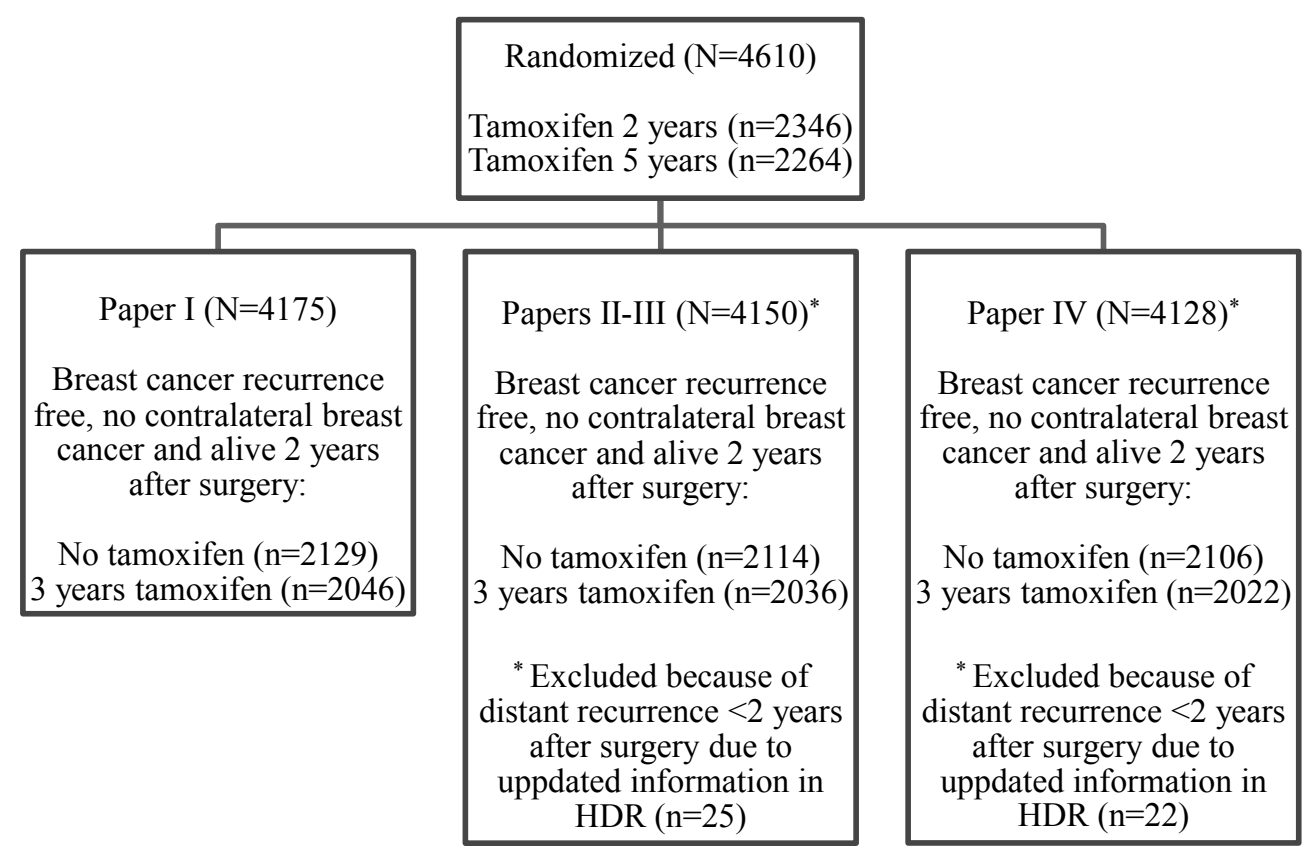

Figure 3. Flow diagram of patients in Papers I-IV including revisions between studies due to updated information in HDR.

\section{Data sources}

All Swedish residents are assigned unique personal identification numbers and these numbers can be used to individually link the information present in the registries. The papers included in this thesis were all based on data from the randomized trial of 2 or 5 years of adjuvant tamoxifen therapy linked to Swedish population-based registries. The Swedish Cancer Registry and the Causes of Death Registry was used to identify new primary malignancies and deaths in Papers I-IV. The Swedish Hospital Discharge Registry (HDR) was used to identify hospitalizations in Papers II-III.

\section{The Hospital Discharge Registry}

The Swedish Hospital Discharge Registry (HDR) was initiated in 1964 [24]. Since 1987 the register covers all public in-patient care. From the register it is possible to retrieve all diagnoses for each hospitalization. The diagnoses in the HDR are based on the Swedish version of the World Health Organization's (WHO) international classification of diseases (ICD). ICD-8 was used until 1986, ICD-9 between 1987 and 1996, and ICD-10 from 1997 and onwards. To analyze the morbidity from cerebrovascular disease and the morbidity from cardiac disease in Paper II and in Paper III, the date and the main diagnosis from HDR or the date and causes of death was used. 


\section{The Causes of Death Registry}

The Causes of Death Registry was established 1961 and records information on all deceased persons registered in the country at the time of death [25]. The cause of death is generally determined from the medical death certificates. In this thesis, the variables date of death and cause of death were used.

\section{The Cancer Registry}

The Swedish Cancer Registry, maintained by the National Board of Health and Welfare, was founded in 1958 and covers the population of Sweden, and contains information about new primary tumors [26]. In this thesis, the code of diagnosis and the date of diagnosis were used.

\section{Statistical methods}

Two methods have been used to estimate the cumulative incidence and the cumulative mortality. The life-table method was used to estimate the cumulative incidence and the cumulative mortality for different time-intervals. To illustrate the cumulative mortality and the cumulative incidence "reversed" Kaplan-Meier curves were displayed. Kaplan-Meier is very similar to the life-table method. It uses the exact times that events occurred rather than the intervals of follow-up [27].

The Cox's proportional hazards model was used, stratified by trial center, to relate treatment group to time period. The analyses were stratified because more patients with stage I tumors were randomized to 2 years of tamoxifen treatment than to 5 years of tamoxifen treatment. From the Cox's proportional hazards model hazard ratios (HRs) and 95\% confidence intervals (CIs) were computed, and the statistical software SPSS was used. All $p$ values were from twosided Wald tests, obtained from the Cox regression models. Results were considered significant at $p<0.05$. Time-dependent variables are those that can change value over the course of the observation period. In order to test time-dependency, i.e. differences in HR between the follow-periods, an interaction term between treatment group and time period was added to the Cox model. 


\section{Results}

\section{Paper I}

In this Paper, a total of 4175 patients were included with a mean age at surgery of 62.6 years in the 2-year group and 62.6 years in the 5-year group. We found that the all-cause mortality was reduced by $19 \%$ (HR 0.81, 95\% CI 0.73-0.90) (Table 2). Furthermore, death from all cardiovascular diseases was statistically significantly lower in the 5-year group than in the 2year group (HR 0.79, 95\% CI 0.63-1.00). This reduction appeared to be mainly associated with a statistically significant reduction in mortality from coronary heart disease (Table 2 and Figure 4). Furthermore, after dividing the follow-up period into two time-periods, we found that the reduction was statistically significant beyond 7 years since start of treatment, but not during the first 7 years. For the whole follow-up period no statistically significant changes in mortality risk from other vascular diseases (other heart disease, cerebrovascular disease, or pulmonary embolism) was seen. We further analyzed the mortality from breast cancer and from endometrial cancer, and the incidence of contralateral breast cancer and endometrial cancer (Table 2). Significant reductions in the 5-year group were seen for breast cancer mortality and for the incidence of contralateral breast cancer. The incidence of endometrial cancer was significantly increased in the 5-year group.

Table 2. Number of events and hazard ratios among patients randomly assigned to 2 years $(n=2129)$ or 5 years $(n=2046)$ of adjuvant tamoxifen therapy.

\begin{tabular}{|c|c|c|c|c|}
\hline & \multicolumn{2}{|c|}{ Number of events } & \multirow[b]{2}{*}{$\begin{array}{c}\text { HR } \\
\text { (5 vs. } 2 \text { years) } \\
(95 \% \mathrm{CI})\end{array}$} & \multirow[b]{2}{*}{$P$ value } \\
\hline & $\begin{array}{c}2 \text {-year } \\
\text { group } \\
n=2129\end{array}$ & $\begin{array}{c}\text { 5-year } \\
\text { group } \\
n=2046\end{array}$ & & \\
\hline \multicolumn{5}{|l|}{ Mortality: } \\
\hline Total & 809 & 671 & $0.81(0.73-0.90)$ & $<0.001$ \\
\hline Breast cancer $(174)^{\mathrm{a}}$ & 428 & 364 & $0.84(0.73-0.96)$ & 0.013 \\
\hline $\mathrm{ER}+(n=2542)$ & 259 & 213 & $0.77(0.64-0.92)$ & 0.005 \\
\hline ER- $(n=603)$ & 62 & 64 & $1.13(0.79-1.62)$ & 0.50 \\
\hline ER status unknown $(n=1030)$ & 107 & 87 & $0.80(0.61-1.07)$ & 0.13 \\
\hline All cardiovascular $(390-459)^{\mathrm{a}}$ & 163 & 136 & $0.79(0.63-1.00)$ & 0.047 \\
\hline Coronary heart disease $(410-414)^{\mathrm{a}}$ & 78 & 54 & $0.67(0.47-0.94)$ & 0.022 \\
\hline Other heart disease $(420-429)^{\mathrm{a}}$ & 22 & 22 & $0.91(0.50-1.65)$ & 0.75 \\
\hline Cerebrovascular disease $(430-438)^{\mathrm{a}}$ & 47 & 40 & $0.81(0.53-1.23)$ & 0.32 \\
\hline Pulmonary embolism $(415.1)^{\mathrm{a}}$ & 5 & 6 & $1.20(0.37-3.93)$ & 0.77 \\
\hline Endometrial cancer $(182)^{\mathrm{a}}$ & 6 & 7 & $1.16(0.39-3.46)$ & 0.79 \\
\hline \multicolumn{5}{|l|}{ Incidence: } \\
\hline Contralateral breast cancer $(174)^{\mathrm{a}}$ & 83 & 55 & $0.68(0.48-0.96)$ & 0.026 \\
\hline Endometrial cancer $(182)^{\mathrm{a}}$ & 24 & 41 & $1.78(1.08-2.95)$ & 0.025 \\
\hline
\end{tabular}

${ }^{a}$ Ninth International Classification of Diseases code numbers.

Abbrevations: HR, hazard ratio; CI, confidence interval; ER, estrogen receptor. 


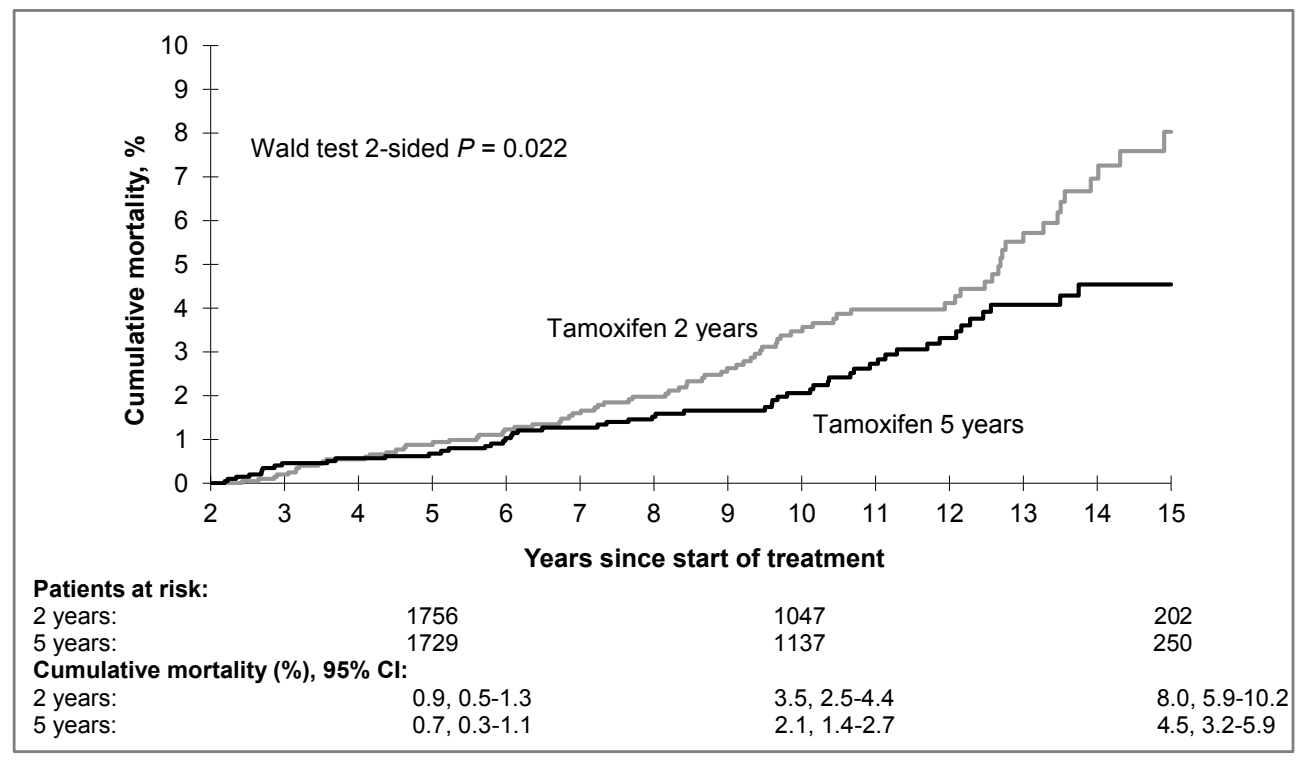

Figure 4. Cumulative mortality from coronary heart disease among patients randomly assigned to 2 years $(n=2129)$ or 5 years $(n=2046)$ of adjuvant tamoxifen therapy. Patients at risk and cumulative risk estimates with $95 \%$ confidence intervals are given at 5,10 and 15 years after start of treatment. 


\section{Paper II}

In this Paper, 4150 patients were analyzed. We investigated the incidence of cerebrovascular diseases that required admission to hospital for the whole follow-up period, as well as during treatment and long-term after treatment. The patients in the present study had an increased risk of cerebrovascular diseases (HR 1.70, 95\% CI 1.05-2.75) during the active treatment phase and a reduced risk after the active treatment period (HR 0.78, 95\% CI 0.63-0.96) (Table 3 and Figure 5). We further analyzed the differences in HR between the two periods. Statistically significant differences were observed for cerebrovascular diseases $(p=0.0033)$ and ischemic stroke $(p=0.014)$. Similar tendencies were observed for haemorrhagic stroke, other and unspecified cerebrovascular diseases and TIA but the differences were not statistically significant.

Paper I showed a tendency to a decreased mortality rate from cerebrovascular disease in the 5year group, compared with the 2-year group. However, with longer-follow up, an increased risk for cerebrovascular mortality was seen during the treatment period (HR 3.18, 95\% CI 1.03-9.87), and a reducted risk was found after treatment was stopped (HR 0.60, 95\% CI 0.40-0.90) (Table 3 and Figure 5). The difference between the two time-periods was significant $(p=0.0066)$. 
Table 3. Morbidity and mortality from cerebrovascular disease according to randomized treatment ( 5 versus 2 years of tamoxifen) during treatment (2-5 years) and after treatment $(>5$ years).

\begin{tabular}{|c|c|c|c|c|c|c|}
\hline & \multirow[b]{2}{*}{$\begin{array}{l}\text { Years since } \\
\text { start of } \\
\text { treatment }\end{array}$} & \multicolumn{2}{|c|}{ Number of events } & \multirow[b]{2}{*}{$\begin{array}{c}\text { HR } \\
\text { (5 versus } 2 \text { years }) \\
(95 \% \mathrm{CI})\end{array}$} & \multirow[b]{2}{*}{$P$ value } & \multirow[b]{2}{*}{$P$ diff. $^{\text {a }}$} \\
\hline & & $\begin{array}{c}2 \text {-year } \\
\text { group } \\
n=2114\end{array}$ & $\begin{array}{c}5 \text {-year } \\
\text { group } \\
n=2036\end{array}$ & & & \\
\hline \multicolumn{7}{|l|}{ Morbidity: } \\
\hline Cerebrovascular diseases & $2-5$ & 27 & 44 & $1.70(1.05-2.75)$ & 0.030 & \\
\hline$(430-8)^{b}$ & $>5$ & 186 & 154 & $0.78(0.63-0.96)$ & 0.020 & 0.0033 \\
\hline Stroke & $2-5$ & 20 & 33 & $1.72(0.99-3.00)$ & 0.056 & \\
\hline$(431,433,434,436)^{\mathrm{b}}$ & $>5$ & 147 & 115 & $0.73(0.57-0.93)$ & 0.011 & 0.0056 \\
\hline Ischemic stroke & $2-5$ & 13 & 26 & $2.10(1.08-4.09)$ & 0.029 & \\
\hline$(433,434)^{b}$ & $>5$ & 102 & 93 & $0.85(0.64-1.12)$ & 0.25 & 0.014 \\
\hline \multirow{2}{*}{$\begin{array}{l}\text { Haemorrhagic stroke } \\
(431)^{b}\end{array}$} & $2-5$ & 5 & 6 & $1.22(0.37-3.99)$ & 0.75 & \\
\hline & $>5$ & 22 & 16 & $0.66(0.35-1.26)$ & 0.21 & 0.37 \\
\hline \multirow{2}{*}{$\begin{array}{l}\text { Other and unspecified } \\
\text { cerebrovascular diseases } \\
(430,432,435,437,438)^{\mathrm{b}}\end{array}$} & $2-5$ & 9 & 16 & $1.85(0.82-4.19)$ & 0.14 & \\
\hline & $>5$ & 67 & 63 & $0.88(0.63-1.25)$ & 0.48 & 0.10 \\
\hline TIA & $2-5$ & 4 & 8 & $2.07(0.62-6.86)$ & 0.24 & \\
\hline$(435)^{b}$ & $>5$ & 10 & 9 & $0.88(0.36-2.18)$ & 0.79 & 0.27 \\
\hline \multicolumn{7}{|l|}{ Mortality: } \\
\hline Cerebrovascular diseases & $2-5$ & 4 & 12 & 3.18 (1.03-9.87) & 0.045 & \\
\hline$(430-8)^{\mathrm{b}}$ & $>5$ & 58 & 38 & $0.60(0.40-0.90)$ & 0.014 & 0.0066 \\
\hline
\end{tabular}

${ }^{\mathrm{a}} P$ value for difference in HR between follow-up periods (during versus after treatment).

${ }^{\mathrm{b}}$ Ninth International Classification of Diseases code numbers.

Abbrevations: HR, hazard ratio; $\mathrm{CI}$, confidence interval. 


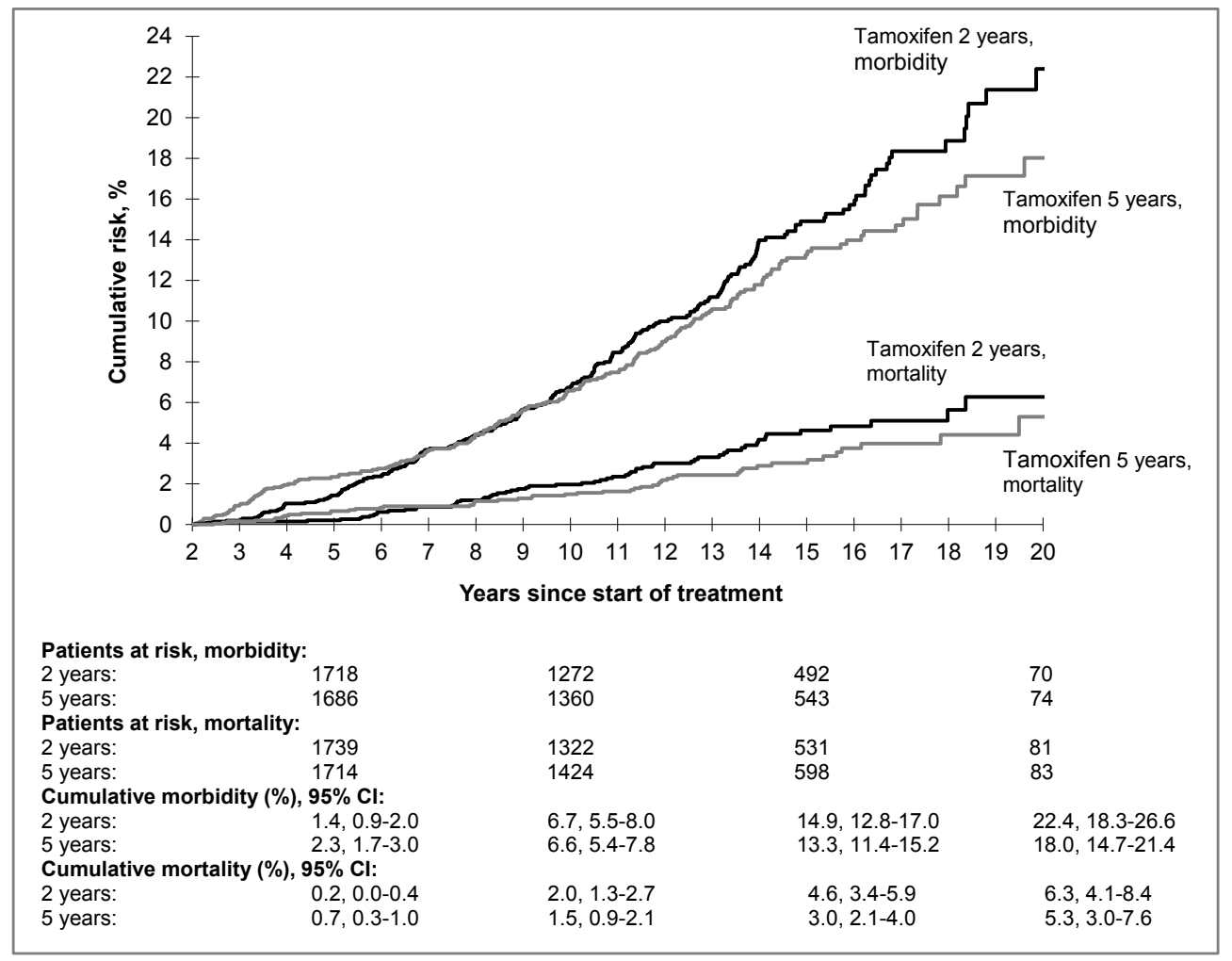

Figure 5. Cumulative morbidity and mortality from cerebrovascular diseases among patients randomly assigned to 2 years $(n=2114)$ or 5 years $(n=2036)$ of adjuvant tamoxifen therapy. Patients at risk and cumulative risk estimates with $95 \%$ confidence intervals are given at 5 , 10,15 and 20 years after start of treatment. 


\section{Paper III}

In Paper I, we reported a significantly reduced mortality from CHD in the comparison of 5 years versus 2 years of postoperative tamoxifen. After an additional of 3 years of follow-up, we here present results among 4150 women on the incidence of cardiac disease requiring admission to hospital, as well as the mortality from CHD and other cardiac diseases. Furthermore, results are shown both during and after treatment, and for the whole follow-up period. For patients with 5 years of tamoxifen treatment compared with those with 2 years of treatment the morbidity from CHD was statistically significantly reduced by $35 \%$ during the active treatment (HR $0.65,95 \%$ CI $0.43-1.00$ ) (Table 4). The mortality from CHD was also statistically significantly decreased. As shown in Figure 6, the effect on CHD mortality was more delayed.

We proceeded to investigate the morbidity of other heart diseases. A statistically significant reduction was observed during treatment, but not after treatment stopped (HR 0.40, 95\% CI $0.25-0.64)$, and the difference in HR between the two periods was significant $(p<0.001)$ (Table 4). The temporal effect is displayed in Figure 7. We also found a decreased risk for heart failure (HF) only during the treatment period (HR $0.30,95 \%$ CI $0.13-0.70$ ) with a significant difference in HR between treatment period and the post-treatment phase $(p<0.0047)$. A reduced risk for atrial fibrillation/flutter (AF) was also observed during treatment, but not after active treatment (HR 0.42, 95\% CI 0.18-0.94), and the difference in HR between the treatment period and the post-treatment period was also statistically significant $(p=0.014)$. The morbidity of all cardiac diseases was significantly reduced during treatment (HR 0.54, 95\% CI 0.40-0.75), but not in the period afterwards. A significant difference in HR between the follow-up periods was observed $(p<0.001)$. No statistically significant changes in the risk for myocardial infarction (MI), as well as the mortality from MI, the mortality from other heart diseases and the mortality from all cardiac diseases was noted. 
Table 4. Morbidity and mortality from cardiac disease according to randomized treatment (5 versus 2 years of tamoxifen) during treatment (2-5 years) and after treatment ( $>5$ years).

\begin{tabular}{|c|c|c|c|c|c|c|}
\hline & \multicolumn{3}{|c|}{ Number of events } & \multirow[b]{2}{*}{$\begin{array}{c}\text { HR } \\
(5 \text { versus } 2 \text { years }) \\
(95 \% \mathrm{CI})\end{array}$} & \multirow[b]{2}{*}{$P$ value } & \multirow[b]{2}{*}{$P$ diff. $^{\text {a }}$} \\
\hline & $\begin{array}{l}\text { Years since } \\
\text { start of } \\
\text { treatment }\end{array}$ & $\begin{array}{c}2 \text {-year } \\
\text { group } \\
n=2114\end{array}$ & $\begin{array}{c}\text { 5-year } \\
\text { group } \\
n=2036\end{array}$ & & & \\
\hline \multicolumn{7}{|l|}{ Morbidity: } \\
\hline All cardiac diseases & $2-5$ & 109 & 58 & $0.54(0.40-0.75)$ & $<0.001$ & \\
\hline$(410-414,420-429)^{\mathrm{b}}$ & $>5$ & 303 & 327 & $1.02(0.87-1.19)$ & 0.79 & $<0.001$ \\
\hline \multirow{2}{*}{$\begin{array}{l}\text { Coronary heart disease } \\
(410-414)^{b}\end{array}$} & $2-5$ & 55 & 35 & $0.65(0.43-1.00)$ & 0.049 & \\
\hline & $>5$ & 197 & 186 & $0.88(0.72-1.08)$ & 0.22 & 0.21 \\
\hline \multirow{2}{*}{$\begin{array}{l}\text { Myocardial infarction } \\
(410)^{\mathrm{b}}\end{array}$} & $2-5$ & 33 & 21 & $0.65(0.38-1.12)$ & 0.12 & \\
\hline & $>5$ & 125 & 105 & $0.78(0.60-1.01)$ & 0.063 & 0.55 \\
\hline \multirow{2}{*}{$\begin{array}{l}\text { Other heart diseases } \\
(420-429)^{\mathrm{b}}\end{array}$} & $2-5$ & 62 & 24 & $0.40(0.25-0.64)$ & $<0.001$ & \\
\hline & $>5$ & 177 & 204 & $1.06(0.87-1.30)$ & 0.55 & $<0.001$ \\
\hline \multirow{2}{*}{$\begin{array}{l}\text { Heart failure } \\
(428)^{\mathrm{b}}\end{array}$} & $2-5$ & 24 & 7 & $0.30(0.13-0.70)$ & 0.0054 & \\
\hline & $>5$ & 88 & 104 & $1.09(0.82-1.45)$ & 0.56 & 0.0047 \\
\hline \multirow{2}{*}{$\begin{array}{l}\text { Atrial fibrillation/flutter } \\
(427.3)^{b}\end{array}$} & $2-5$ & 20 & 8 & $0.42(0.18-0.94)$ & 0.036 & \\
\hline & $>5$ & 65 & 86 & $1.26(0.91-1.74)$ & 0.16 & 0.014 \\
\hline \multicolumn{7}{|l|}{ Mortality: } \\
\hline \multirow{2}{*}{$\begin{array}{l}\text { All cardiac diseases } \\
(410-414,420-429)^{b}\end{array}$} & $2-5$ & 19 & 12 & $0.65(0.32-1.34)$ & 0.25 & \\
\hline & $>5$ & 110 & 101 & $0.87(0.66-1.14)$ & 0.31 & 0.46 \\
\hline \multirow{2}{*}{$\begin{array}{l}\text { Coronary heart disease } \\
(410-414)^{b}\end{array}$} & $2-5$ & 17 & 12 & $0.73(0.35-1.53)$ & 0.40 & \\
\hline & $>5$ & 84 & 64 & $0.72(0.52-0.99)$ & 0.044 & 0.96 \\
\hline \multirow{2}{*}{$\begin{array}{l}\text { Myocardial infarction } \\
(410)^{\mathrm{b}}\end{array}$} & $2-5$ & 14 & 10 & $0.73(0.33-1.65)$ & 0.46 & \\
\hline & $>5$ & 49 & 35 & $0.67(0.43-1.03)$ & 0.069 & 0.94 \\
\hline \multirow{2}{*}{$\begin{array}{l}\text { Other heart diseases } \\
(420-429)^{\mathrm{b}}\end{array}$} & $2-5$ & 2 & 0 & - & - & \\
\hline & $>5$ & 26 & 37 & $1.28(0.77-2.12)$ & 0.34 & - \\
\hline
\end{tabular}

${ }^{\mathrm{a}} P$ value for difference in HR between follow-up periods (during versus after treatment).

${ }^{b}$ Ninth International Classification of Diseases code numbers.

Abbrevations: HR, hazard ratio; CI, confidence interval. 


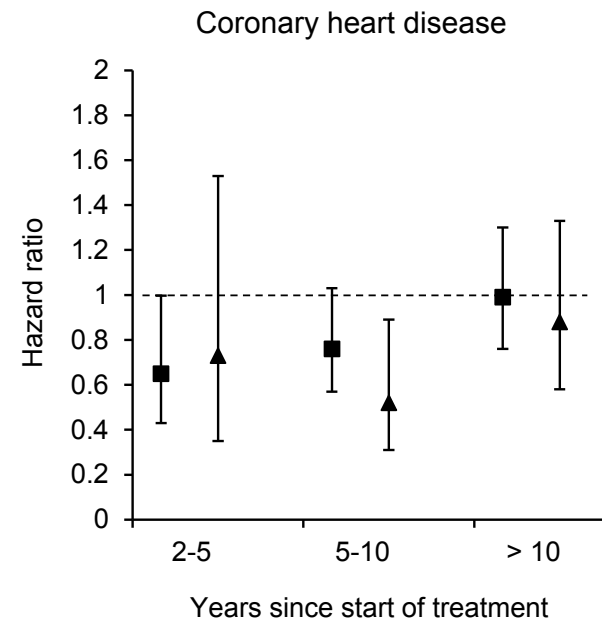

Figure 6. Hazard ratios for morbidity ( $\boldsymbol{\square})$ and mortality $(\boldsymbol{\Delta})$ from coronary heart disease among patients randomly assigned to 5 years $(n=2036)$ of adjuvant tamoxifen therapy compared to 2 years $(n=2114)$ of adjuvant tamoxifen therapy. Hazard ratios with $95 \%$ confidence intervals are given at 2-5, 5-10 and more than 10 years after start of treatment. Test for trend: $P=0.078$ (morbidity), $P=0.39$ (mortality).

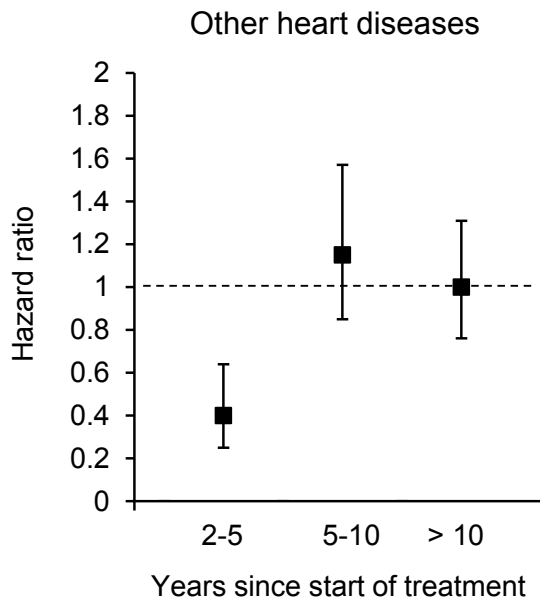

Figure 7. Hazard ratios for morbidity from other heart diseases among patients randomly assigned to 5 years $(n=2036)$ of adjuvant tamoxifen therapy compared to 2 years $(n=2114)$ of adjuvant tamoxifen therapy. Hazard ratios with $95 \%$ confidence intervals are given at 2-5, 510 and more than 10 years after start of treatment. Test for trend: $P=0.0074$. 


\section{Paper IV}

In the study, 4128 patients were included. Results of the incidence and the mortality from secondary cancers, as well as the occurrence of distance recurrences are presented. Results are shown for different time-intervals defined as: Entire follow-up period ( $>2$ years), during treatment (2-5 years) and after treatment ( $>5$ years).

The total number of patients with second primary cancers was 413 in the 5-year group and 395 in the 2-year group, and the HR was 1.01 (95\% CI, 0.88-1.16) as shown in Table 5. In the five years group the incidence of lung cancer was halved (HR 0.45, 95\% CI 0.27-0.77), and lung cancer mortality was decreased (Table 6 and Figure 8). For endometrial cancer an increased risk of $83 \%$ was observed in the 5-year group (HR 1.83, 95\% CI 1.19-2.81). As shown in Table 6 and in Figure 9, the risk of endometrial cancer was significantly increased during treatment, but appeared to decrease over time. Furthermore, the risk of primary cancer in the contralateral breast was decreased (HR 0.73, 95\% CI 0.56-0.96), also in the period after treatment was stopped (Table 7 and Figure 10). We further analyzed the risk of distant recurrence and breast cancer mortality among patients with ER-positive or ER-unknown diseases. Among patients with 5-years of tamoxifen, the risk of distant recurrence was decreased by $21 \%$ (HR $0.79,95 \%$ CI $0.69-0.89$ ), and statistically significant reductions were observed both during treatment and in the five year period after treatment was terminated (Table 8 and Figure 11). The breast cancer mortality was reduced, especially during the posttreatment phase (> 5 years) (HR 0.80, 95\% CI 0.69-0.93) (Table 9 and Figure 12).

Table 5. Incidence of new primary malignancies for some selected diagnoses allocated by duration of tamoxifen treatment.

\begin{tabular}{|c|c|c|c|c|}
\hline \multirow[b]{2}{*}{ Cancer site or type ${ }^{b}$} & \multicolumn{2}{|c|}{$\begin{array}{l}\text { Number of new primary } \\
\text { malignances }{ }^{\mathrm{a}}\end{array}$} & \multirow[b]{2}{*}{$\begin{array}{c}\text { HR } \\
\text { (5 versus } 2 \text { years) } \\
(95 \% \mathrm{CI})\end{array}$} & \multirow[b]{2}{*}{$P$ value } \\
\hline & $\begin{array}{c}2 \text {-year } \\
\text { group } \\
n=2106\end{array}$ & $\begin{array}{c}5 \text {-year } \\
\text { group } \\
n=2022\end{array}$ & & \\
\hline Colon-rectum (153-154) & $47(7)$ & $52(1)$ & $1.05(0.71-1.56)$ & 0.81 \\
\hline Lung (162) & $41(4)$ & $20(3)$ & $0.45(0.27-0.77)$ & 0.0038 \\
\hline Contralateral breast (174) & $121(15)$ & $92(14)$ & $0.73(0.56-0.96)$ & 0.022 \\
\hline Endometrium (182) & $32(2)$ & $60(4)$ & $1.83(1.19-2.81)$ & 0.0059 \\
\hline Total $^{\mathrm{c}}$ & $395(43)$ & $413(33)$ & $1.01(0.88-1.16)$ & 0.91 \\
\hline
\end{tabular}


Table 6. Secondary cancer incidence and mortality without prior recurrence or contralateral breast cancer according to randomized treatment ( 5 versus 2 years of tamoxifen) for the entire follow-up ( $>2$ years after start of treatment), during treatment (2-5 years) and after treatment $(>5$ years $)$.

\begin{tabular}{|c|c|c|c|c|c|}
\hline \multirow[b]{2}{*}{ Cancer site or type ${ }^{a}$} & \multirow[b]{2}{*}{$\begin{array}{l}\text { Years since } \\
\text { start of } \\
\text { treatment }\end{array}$} & \multicolumn{2}{|c|}{ Number of events } & \multirow[b]{2}{*}{$\begin{array}{c}\mathrm{HR} \\
(5 \text { versus } 2 \text { years }) \\
(95 \% \mathrm{CI}) \\
\end{array}$} & \multirow[b]{2}{*}{$P$ value } \\
\hline & & $\begin{array}{c}2 \text {-year } \\
\text { group } \\
n=2106 \\
\end{array}$ & $\begin{array}{c}5 \text {-year } \\
\text { group } \\
n=2022 \\
\end{array}$ & & \\
\hline \multicolumn{6}{|l|}{ Incidence: } \\
\hline \multirow[t]{3}{*}{ Lung cancer (162) } & $2-5$ & 6 & 2 & $0.34(0.07-1.70)$ & 0.19 \\
\hline & $>2$ & 41 & 20 & $0.45(0.27-0.77)$ & 0.0038 \\
\hline & $>5$ & 35 & 18 & $0.47(0.27-0.83)$ & 0.0096 \\
\hline \multirow[t]{3}{*}{ Endometrial cancer (182) } & $2-5$ & 6 & 19 & $3.33(1.33-8.34)$ & 0.010 \\
\hline & $>2$ & 32 & 60 & $1.83(1.19-2.81)$ & 0.0059 \\
\hline & $>5$ & 26 & 41 & $1.50(0.91-2.45)$ & 0.11 \\
\hline \multicolumn{6}{|l|}{ Mortality: } \\
\hline \multirow[t]{3}{*}{ Lung cancer (162) } & $2-5$ & 2 & 3 & $1.52(0.25-9.10)$ & 0.65 \\
\hline & $>2$ & 33 & 19 & $0.52(0.30-0.92)$ & 0.024 \\
\hline & $>5$ & 31 & 16 & $0.46(0.25-0.85)$ & 0.012 \\
\hline
\end{tabular}

${ }^{a}$ Ninth International Classification of Diseases code numbers.

Abbrevations: HR, hazard ratio; CI, confidence interval.

Table 7. Contralateral breast cancer incidence without prior recurrences according to randomized treatment ( 5 versus 2 years of tamoxifen) for the entire follow-up ( $>2$ years after start of treatment), during treatment (2-5 years) and after treatment ( $>5$ years).

\begin{tabular}{llcccll}
\hline & & \multicolumn{2}{c}{ Number of events } & & \\
\cline { 2 - 4 } & $\begin{array}{l}\text { Years since } \\
\text { start of }\end{array}$ & $\begin{array}{c}2 \text {-year } \\
\text { group }\end{array}$ & $\begin{array}{c}5 \text {-year } \\
\text { group }\end{array}$ & $\begin{array}{c}\text { HR } \\
(5 \text { versus 2 years })\end{array}$ & \\
& treatment & $(n=2106)$ & $(n=2022)$ & $(95 \%$ CI $)$ & $P$ value \\
\hline All ER-status & $2-5$ & 29 & 22 & $0.78(0.45-1.36)$ & 0.38 \\
& $>2$ & 121 & 92 & $0.73(0.56-0.96)$ & 0.022 \\
& $>5$ & 92 & 70 & $0.71(0.52-0.97)$ & 0.033 \\
\hline
\end{tabular}

Abbrevations: HR, hazard ratio; CI, confidence interval; ER, estrogen receptor. 
Table 8. Distant recurrence according to randomized treatment ( 5 versus 2 years of tamoxifen) for the entire follow-up ( $>2$ years after start of treatment), during treatment (2-5 years) and after treatment ( $>5$ years).

\begin{tabular}{|c|c|c|c|c|c|}
\hline \multirow[b]{2}{*}{ Estrogen receptor status } & \multirow[b]{2}{*}{$\begin{array}{l}\text { Years since } \\
\text { start of } \\
\text { treatment }\end{array}$} & \multicolumn{2}{|c|}{ Number of events } & \multirow[b]{2}{*}{$\begin{array}{c}\text { HR } \\
\text { (5 versus } 2 \text { years) } \\
(95 \% \mathrm{CI})\end{array}$} & \multirow[b]{2}{*}{$P$ value } \\
\hline & & $\begin{array}{c}2 \text {-year } \\
\text { group } \\
(n=2106)\end{array}$ & $\begin{array}{c}5 \text {-year } \\
\text { group } \\
(n=2022)\end{array}$ & & \\
\hline \multirow{3}{*}{ ER+ or ER unknown } & $2-5$ & 228 & 174 & $0.75(0.62-0.92)$ & 0.0047 \\
\hline & $>2$ & 513 & 425 & $0.79(0.69-0.89)$ & 0.0003 \\
\hline & $>5$ & 285 & 251 & $0.81(0.69-0.96)$ & 0.017 \\
\hline
\end{tabular}

Abbrevations: HR, hazard ratio; CI, confidence interval; ER, estrogen receptor.

Table 9. Breast cancer mortality according to randomized treatment ( 5 versus 2 years of tamoxifen) for the entire follow-up ( $>2$ years after start of treatment), during treatment (2-5 years) and after treatment ( $>5$ years).

\begin{tabular}{llcccll}
\hline & & \multicolumn{2}{c}{ Number of events } & & \\
\cline { 2 - 4 } & $\begin{array}{l}\text { Years since } \\
\text { start of }\end{array}$ & $\begin{array}{c}\text { 2-year } \\
\text { group }\end{array}$ & $\begin{array}{c}\text { 5-year } \\
\text { group }\end{array}$ & & $\begin{array}{c}\text { HR } \\
(5 \text { versus 2 years })\end{array}$ & \\
Estrogen receptor status & treatment & $n=2106$ & $n=2022$ & $(95 \%$ CI $)$ & $P$ value \\
\hline ER+ or ER unknown & $2-5$ & 104 & 86 & $0.82(0.62-1.09)$ & 0.18 \\
& $>2$ & 455 & 386 & $0.80(0.70-0.92)$ & 0.0017 \\
& $>5$ & 351 & 300 & $0.80(0.69-0.93)$ & 0.0046 \\
\hline
\end{tabular}

Abbrevations: HR, hazard ratio; CI, confidence interval; ER, estrogen receptor. 


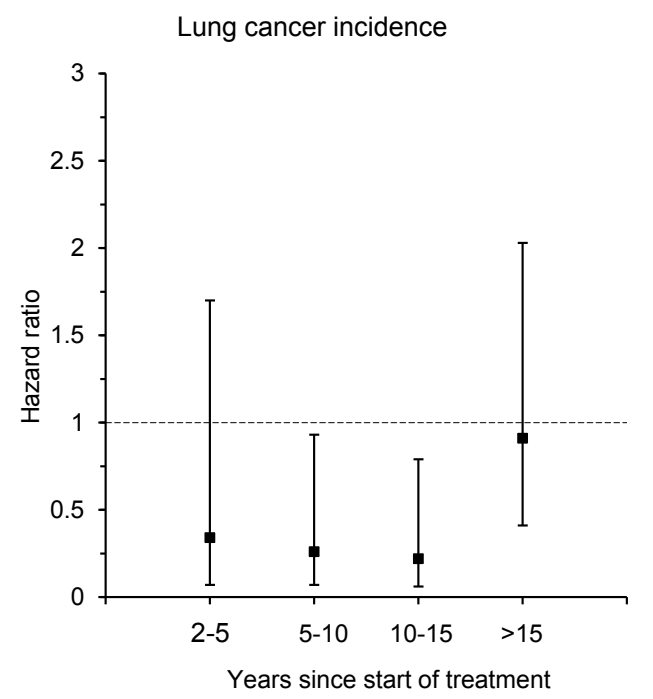

Figure 8. Hazard ratios with $95 \%$ confidence intervals for lung cancer incidence among patients (all ER-status) without prior recurrence or contralateral breast cancer randomly assigned to 5 years $(n=2022)$ of adjuvant tamoxifen therapy compared to 2 years $(n=2106)$ of adjuvant tamoxifen therapy.

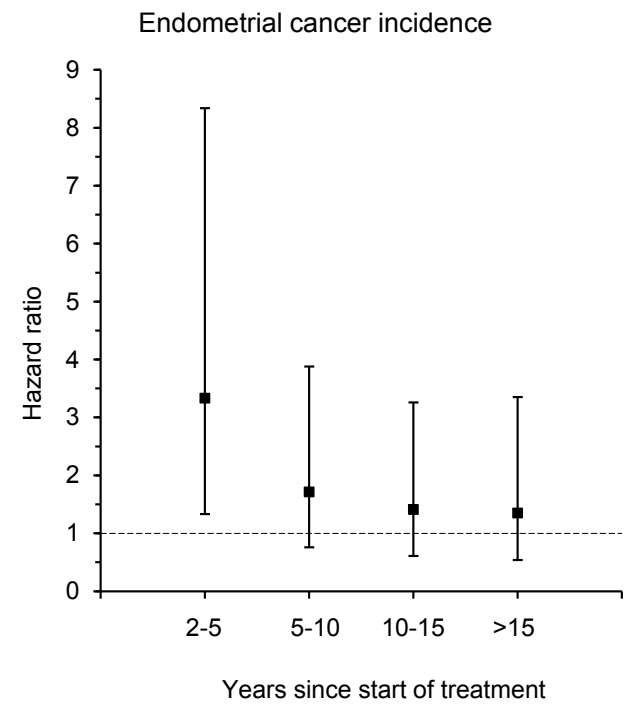

Figure 9. Hazard ratios with $95 \%$ confidence intervals for endometrial cancer incidence among patients (all ER-status) without prior recurrence or contralateral breast cancer randomly assigned to 5 years $(n=2022)$ of adjuvant tamoxifen therapy compared to 2 years $(n=2106)$ of adjuvant tamoxifen therapy. 
Contralateral breast cancer

All ER-status

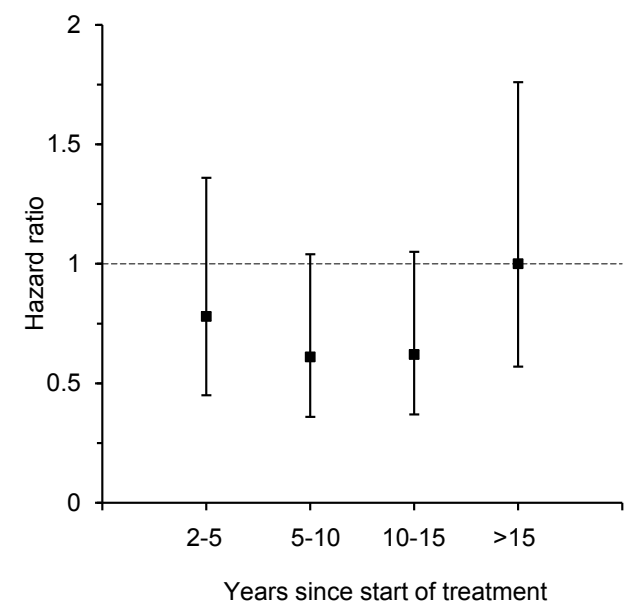

Figure 10. Hazard ratios with $95 \%$ confidence intervals for contralateral breast cancer without prior recurrences among patients (all ER-status) randomly assigned to 5 years $(n=2022)$ of adjuvant tamoxifen therapy compared to 2 years $(n=2106)$ of adjuvant tamoxifen therapy.

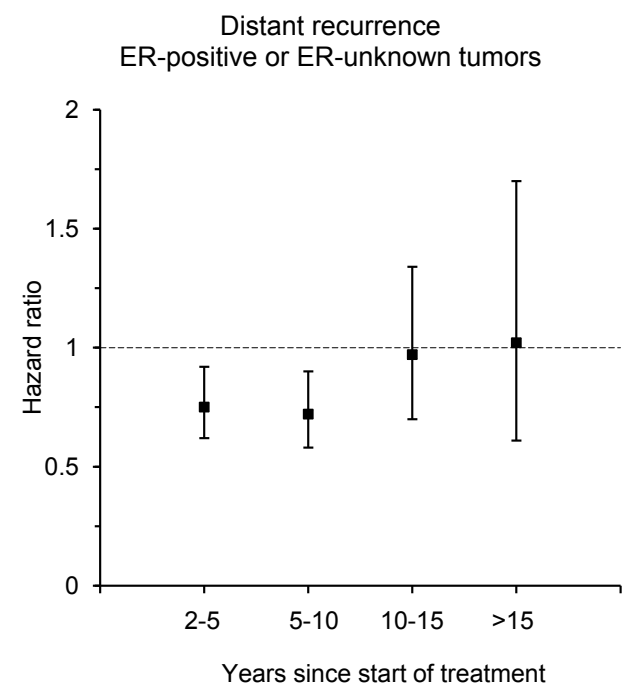

Figure 11. Hazard ratios with $95 \%$ confidence intervals for distant recurrence of ER-positive or ER-unknown tumors among patients randomly assigned to 5 years $(n=1741)$ of adjuvant tamoxifen therapy compared to 2 years $(n=1791)$ of adjuvant tamoxifen therapy. 
Breast cancer mortality

ER-positive or ER-unknown tumors

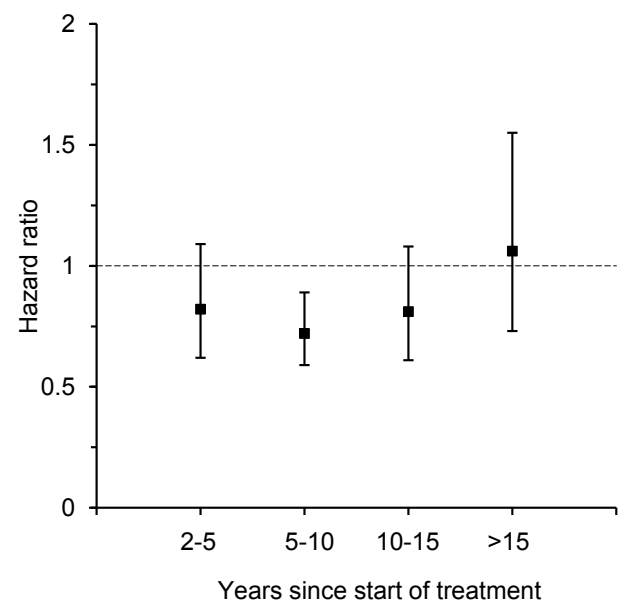

Figure 12. Hazard ratios with $95 \%$ confidence intervals for mortality from breast cancer among patients with ER-positive or ER-unknown tumors randomly assigned to 5 years $(n=1741)$ of adjuvant tamoxifen therapy compared to 2 years $(n=1791)$ of adjuvant tamoxifen therapy. 


\section{Overview of outcomes in Papers I-IV}

In table 10, an overview of outcomes in Papers I-IV is displayed.

Table 10. Overview of outcomes in Papers I-II. Statistically significant percentage change in event rates of 5 versus 2 years of tamoxifen are marked in bold. Non-significant percentage change in event rates are given in parentheses.

\begin{tabular}{|c|c|c|c|}
\hline $\begin{array}{l}\text { Paper I } \\
\text { Median follow-up: } 12 \text { years }{ }^{\mathrm{a}}\end{array}$ & $\begin{array}{l}\text { Entire } \\
\text { follow-up } \\
\text { (>2 years) }\end{array}$ & $\begin{array}{l}\text { During } \\
\text { treatment } \\
\text { (2-5 years) }\end{array}$ & $\begin{array}{l}\text { After } \\
\text { treatment } \\
(>5 \text { years })\end{array}$ \\
\hline \multicolumn{4}{|l|}{ Incidence (new primary malignancies) } \\
\hline Contralateral breast cancer & $-32 \%$ & - & - \\
\hline Endometrial cancer & $+78 \%$ & - & - \\
\hline \multicolumn{4}{|l|}{ Mortality } \\
\hline Total & $-19 \%$ & - & - \\
\hline Breast cancer & $-16 \%$ & - & - \\
\hline Endometrial cancer & $(+16 \%)$ & - & - \\
\hline All cardiovascular & $-11 \%$ & - & - \\
\hline Coronary heart disease & $-33 \%$ & - & - \\
\hline Other heart disease & $(-9 \%)$ & - & - \\
\hline Cerebrovascular disease & $(-19 \%)$ & - & - \\
\hline Pulmonary embolism & $(+20 \%)$ & - & - \\
\hline $\begin{array}{l}\text { Paper II } \\
\text { Median follow-up: } 13 \text { years }{ }^{\text {b }}\end{array}$ & $\begin{array}{l}\text { Entire } \\
\text { follow-up } \\
\text { (>2 years) }\end{array}$ & $\begin{array}{l}\text { During } \\
\text { treatment } \\
\text { (2-5 years) }\end{array}$ & $\begin{array}{l}\text { After } \\
\text { treatment } \\
(>5 \text { years })\end{array}$ \\
\hline \multicolumn{4}{|l|}{ Incidence (hospitalization) } \\
\hline Cerebrovascular diseases & $(-11 \%)$ & $+70 \%$ & $-12 \%$ \\
\hline Stroke & $(-16 \%)$ & $(+72 \%)$ & $-27 \%$ \\
\hline Ischemic stroke & $(-2 \%)$ & $+210 \%$ & $(-15 \%)$ \\
\hline Haemorrhagic stroke & $(-24 \%)$ & $(+22 \%)$ & $(-34 \%)$ \\
\hline Other and unspecified cerebrovascular diseases & $(-1 \%)$ & $(+85 \%)$ & $(-12 \%)$ \\
\hline TIA & $(+22 \%)$ & $(+207 \%)$ & $(-12 \%)$ \\
\hline \multicolumn{4}{|l|}{ Mortality } \\
\hline Cerebrovascular diseases & $(-25 \%)$ & $+318 \%$ & $-40 \%$ \\
\hline
\end{tabular}

${ }^{a}$ Follow-up time is calculated from date of surgery until date of death or censored at December 31, 2000.

${ }^{\mathrm{b}}$ Follow-up time is calculated from date of surgery until date of death or censored at December 31, 2003. For the analysis of hospital admissions and/or mortality of cerebrovascular diseases, the median follow-up was 12 years from the date of surgery. 
Table 10 (continued). Overview of outcomes in Papers III-IV. Statistically significant percentage change in event rates of 5 versus 2 years of tamoxifen are marked in bold. Nonsignificant percentage change in event rates are given in parentheses.

\begin{tabular}{|c|c|c|c|}
\hline $\begin{array}{l}\text { Paper III } \\
\text { Median follow-up: } 13 \text { years }\end{array}$ & $\begin{array}{l}\text { Entire } \\
\text { follow-up } \\
(>2 \text { years })\end{array}$ & $\begin{array}{l}\text { During } \\
\text { treatment } \\
\text { (2-5 years) }\end{array}$ & $\begin{array}{l}\text { After } \\
\text { treatment } \\
(>5 \text { years })\end{array}$ \\
\hline \multicolumn{4}{|l|}{ Incidence (hospitalization) } \\
\hline All cardiac diseases & $(-10 \%)$ & $-46 \%$ & $(+2 \%)$ \\
\hline Coronary heart disease & $-17 \%$ & $-35 \%$ & $(-12 \%)$ \\
\hline Myocardial infarction & $-25 \%$ & $(-35 \%)$ & $(-22 \%)$ \\
\hline Other heart diseases & $(-10 \%)$ & $-60 \%$ & $(+6 \%)$ \\
\hline Heart failure & $(-7 \%)$ & $-70 \%$ & $(+9 \%)$ \\
\hline Atrial fibrillation/flutter & $(+7 \%)$ & $-48 \%$ & $(+26 \%)$ \\
\hline \multicolumn{4}{|l|}{ Mortality } \\
\hline All cardiac diseases & $(-16 \%)$ & $(-35 \%)$ & $(-17 \%)$ \\
\hline Coronary heart diseases & $-28 \%$ & $(-17 \%)$ & $-18 \%$ \\
\hline Myocardial infarction & $(-32 \%)$ & $(-27 \%)$ & $(-33 \%)$ \\
\hline Other heart diseases & $(+19 \%)$ & - & $(+28 \%)$ \\
\hline $\begin{array}{l}\text { Paper IV } \\
\text { Median follow-up: } 17 \text { years }{ }^{\mathrm{d}}\end{array}$ & $\begin{array}{l}\text { Entire } \\
\text { follow-up } \\
(>2 \text { years })\end{array}$ & $\begin{array}{l}\text { During } \\
\text { treatment } \\
\text { (2-5 years) }\end{array}$ & $\begin{array}{l}\text { After } \\
\text { treatment } \\
(>5 \text { years })\end{array}$ \\
\hline \multicolumn{4}{|l|}{ Incidence (new primary malignancies) } \\
\hline Lung cancer & $-55 \%$ & $(-66 \%)$ & $-53 \%$ \\
\hline Endometrial cancer & $+83 \%$ & $+333 \%$ & $(+50 \%)$ \\
\hline Colorectal cancer & $(+5 \%)$ & - & - \\
\hline Contralateral breast cancer & $-27 \%$ & $(-22 \%)$ & $-29 \%$ \\
\hline Total (first new primary malignancy) & $(+1 \%)$ & - & - \\
\hline \multicolumn{4}{|l|}{ Mortality } \\
\hline Lung cancer & $-48 \%$ & $(+52 \%)$ & $-54 \%$ \\
\hline Endometrial cancer & $(+228 \%)$ & - & $(+302 \%)$ \\
\hline Breast cancer (ER+ or ER unknown) & $-20 \%$ & $(-18 \%)$ & $-20 \%$ \\
\hline Distant recurrence (ER+ or ER unknown) & $-21 \%$ & $-25 \%$ & $-19 \%$ \\
\hline
\end{tabular}

${ }^{\mathrm{c}}$ Follow-up time is calculated from date of surgery until date of death or censored at December 31, 2003. For the analysis of hospital admissions and/or mortality of all cardiac diseases, the median follow-up was 12 years from the date of surgery.

${ }^{\mathrm{d}}$ Follow-up time is calculated from date of surgery until date of death or censored at December 31, 2009 


\section{Discussion of results}

\section{Cardiovascular disease}

Coronary heart disease (CHD)

Results from other investigations support our findings of a decreased risk of CHD [19, 20, 28, 29]. There are few reports on the long-term effects of tamoxifen on cardiac morbidity. Two randomized trials have reported an early benefit of tamoxifen on the incidence of hospital admission for myocardial infarction (MI) and other ischemic heart diseases [19, 20]. The results of an early benefit of tamoxifen on cardiac diseases are consistent with our results. In a prevention trial including women aged 35-70 years with increased risk for breast cancer, randomized to receive either 5 years of tamoxifen or placebo, no statistically significant differences of any cardiovascular events between treatment groups were found [21]. However, when the active treatment period was compared with the post-treatment period, a nonstatistically significantly reduction of MI incidence appeared during active treatment phase. Deaths from MI were not reduced, and the risk for other heart diseases tended to decrease after treatment, but the number of events was small.

\section{Heart failure $(H F)$}

We found a significantly reduced risk of HF during the active treatment phase. Tamoxifenrelated risks of $\mathrm{HF}$ are unclear. One explanation could be an indirect effect of tamoxifen lowering LDL cholesterol levels. Several studies have demonstrated that the most common cause of HF is CHD [30, 31]. However, in our study when censoring for earlier events of CHD during the treatment period, the reduction of HF was still significant, suggesting that this effect is not entirely mediated by the CHD reduction. Note that we were only able to adjust for hospitalized cases of CHD and that MI may have a "silent" course. It has been reported that approximately one third of all MI in women were "silent" [32, 33]. CRP has been found to predict the incidence of HF [34-36] and another explanation for the riskreducing effect on HF could be the anti-inflammatory effect of tamoxifen [15].

\section{Atrial fibrillation/flutter $(A F)$}

We also saw that the risk of AF was reduced in the 5-year treatment group. Several cardiac conditions are associated with increased AF risk. Based on data from the Framingham cohort, Benjamin et al. reported that especially HF was associated with a substantial increased risk of AF [37]. However, adjusting for HF or CHD did not change the risk estimates in our study, although the difference was not statistically significant.

\section{Cerebrovascular disease}

We found significantly increased risks of both cerebrovascular diseases and mortality from cerebrovascular diseases during treatment and significantly decreased risks after treatment. Meta-analyses of breast cancer risk reduction and treatment trials show that tamoxifen is associated with an increased risk of stroke [22, 23, 38]. However, many of these studies have a limited follow-up time and there is little information on the period after treatment was 
stopped. We found two studies that not show a reduced risk of cerebrovascular disease during the post-treatment phase $[19,21]$. In these two studies both pre- and postmenopausal patients were included and the number of events was quite small after termination of treatment.

Because tamoxifen increases the risk of thromboembolism, its use may be associated with cerebral venous thrombosis [23]. As tamoxifen is also associated with several of positive effects, for example lipid-lowering properties and decreasing the levels of CRP, the timedependent effects of tamoxifen on cerebrovascular disease might be the result of a combination of positive and negative effects of the treatment. However, as the biological mechanisms are poorly understood, the long-term effects of tamoxifen should be interpreted with caution.

\section{Cancer}

\section{Lung cancer}

To our knowledge, no studies have reported the long-term effect of tamoxifen on lung cancer incidence. In our study with a median follow-up of more than 17 years, a statistically significant reduction of lung cancer incidence, as well as lung cancer mortality up to 10 years after treatment was found. Even when excluding tumors diagnosed as lung adenocarcinoma or lung cancer UNS, which may represent recurrences of breast cancer misclassified as lung cancer, the incidence was still reduced. The use of anti-estrogens has been associated with prolonged survival among females with lung cancer [39, 40]. In an overview of randomized trials (about 5 years of tamoxifen versus not) no strong association between adjuvant tamoxifen and lung cancer mortality was reported [9]. It is unclear why use of tamoxifen reduces the lung cancer incidence. It has been suggested that ER $\beta$ inhibits proliferation and promotes differentiation in the lung $[41,42]$. Tamoxifen has partial estrogen-like effects in the body and could thus activate ER $\beta$ in the lung. As we discussed earlier, tamoxifen treatment has been shown to reduce markers of inflammation, e.g. CRP, especially among postmenopausal women [15]. This is of interest, since inflammation is thought to have a role in lung carcinogenesis [43, 44].

\section{Endometrial cancer}

It is well known that tamoxifen use increases the risk of endometrial cancer [10]. Few studies have reported the long-term effects of tamoxifen on endometrial cancer. In a prevention study, Cuzick et al. found among both pre- and postmenopaual women an increased risk for endometrial cancers [21]. The increased risk was confined to the active treatment period.

\section{Contralateral breast cancer}

Results from randomized trials indicate that treatment with tamoxifen for primary breast cancer reduces the risk for contralateral breast cancer. However, less is known about the duration of the risk reduction and the impact of factors such as age and menopausal status. We found no studies of postmenopausal patients where risk by time since diagnosis of the first breast cancer was adressed, maybe because most of the studies had low statistical power for assessing long-term risk. However, in a recently published meta-analysis of prevention 
trials, including pre- and postmenopausal women with increased risk for breast cancer, the benefit of tamoxifen was extended to at least 10 years, especially for ER-positive cancers [45]. In a case-control study among women less than 55 years with a median duration of tamoxifen for 2.7 years a significantly decreased risk of contralateral breast cancer was observed during 0-5 years after diagnosis, and a non-significantly decreased risk was reported during the subsequent 5-10 years [46]. From a controlled randomized trial with premenopausal breast cancer patients it was reported that the reduced risk of contralateral breast cancer was persistent during the whole follow-up time, that is the effect of tamoxifen was not significantly dependent on time [47].

\section{Colorectal cancer}

We further analyzed the incidence of colorectal cancer, and found no changes in the incidence of colorectal cancer between the treatment groups. Our results were consistent with overviews of randomized trial of tamoxifen $[9,10]$.

\section{Distant recurrence and breast cancer mortality}

Furthermore, we found among postmenopausal patients with ER-positive or ER-unknown disease a significant reduction in distant recurrences both during active treatment and a few years after treatment was stopped. For breast cancer mortality most of the reduction was observed during the first years after treatment was stopped. These results are in agreement with those from the EBCTCG overviews $[9,10]$. 


\section{Discussion of methods}

The studies are based on treatment data from a randomized clinical trial combined with outcome data mostly from national registers. The completeness and quality of the Swedish population-based registries used in this thesis are high. In the year 1978 the estimated deficit was $4 \%$ of the total cancer incidence that year, and for the year 1998 it was an underreporting of $3.7 \%$ of individuals with malignant disease in the Swedish Cancer Registry $[48,49]$. The number of dropouts of main diagnosis in HDR has been very low. Between 1980 and 2003 the dropout rate was about $1 \%$ per year [50]. An earlier validation study showed a good precision of main diagnosis in the HDR for cerebrovascular diseases with sensitivity $95.7 \%$ and specificity $99.5 \%$ [51]. For cardiac diseases validation studies of HDR have shown high positive predicted values for cardiac diseases [50]. Causes of death were obtained from the Swedish Cause of Death Registry. In the year 2000 the estimated deficit was $0.6 \%$ of all causes of deaths, and in the year 2008 the estimated deficit was $0.8 \%$ [52]. In a study from 2009 it was reported that among all death certificates during 1995 in Sweden, malignant tumors and CHD respectively had the highest accuracy with $90 \%$ respectively $87 \%$ [53].

Cox modelling was the main analytic tool. Analyses were done by intention-to-treat, which avoids the possibility of any bias associated with loss, mis-allocation or non-adherence of participants [27]. To avoid the possible confounding effect of a new or recurrent breast cancer and subsequent treatment, each patient was considered to be at risk for the analyzed events from 2 years after surgery, but not beyond the timepoint of any recurrence or contralateral breast cancer. To test if age or dose of tamoxifen modified the effect of tamoxifen on the outcome of interest, interactions terms were added to the Cox model. However, no significant interactions were found. The statistical power was high in many analyses, such as the incidence and mortality from CHD, to detect significant differences (Paper III). However, concerning the tamoxifen effects on rare events, such as the incidence of many types of new primary malignancies (Paper IV), the statistical power was small and was reflected in wide confidence intervals. In such cases, a meta-analysis could be performed to aggregate information from this and other future studies in order to achieve a higher statistical power. 


\section{Conclusions}

Based on the findings on 5 years of adjuvant tamoxifen compared with 2 years of adjuvant tamoxifen treatment, the following conclusions can be drawn from Papers I-IV included in this thesis:

Five years of tamoxifen significantly reduces the risk of coronary heart disease. This was also the case for heart failure and atrial fibrillation/flutter. The risk-reducing effect on cardiac morbidity was most apparent during the active treatment period, and tended to diminish in the subsequent years. For coronary heart disease mortality a decreased risk was observed after the active treatment.

The incidence and mortality of cerebrovascular disease were increased during the active treatment phase, and reduced after treatment was stopped. Similar results were seen for subgroups of cerebrovascular diseases such as stroke and ischemic stroke.

Those with 5 years of treatment showed a lower risk of lung cancer up to 10 years after termination of active treatment. An increased risk for endometrial cancer was observed, but appeared to decrease over time. The risk of contralateral breast cancer was reduced up to 10 years after treatment was terminated. For all secondary cancers no change in risk between the treatment arms was found. A reduced risk of distant recurrence was observed during treatment and a few years after treatment was stopped. Also, the breast cancer mortality was reduced with most of the reduction a few years after active treatment. 


\section{Acknowledgements}

I wish to express my gratitude to the following people:

John Carstensen, my supervisor, for his enthusiastic guidance and for sharing his broad knowledge in the field of epidemiology and statistics.

Olle Stål, my co-supervisor, for useful support and criticism of Papers II-IV.

Bo Nordenskjöld, my co-supervisor, for introducing me into this project and fruitful coauthorship.

My co-authors for useful support and contributions to the papers in this thesis.

Colleagues at Regional Cancer Center South East for creating friendly and enjoyable work environment.

My parents Christer and Imri for your love and support.

My brother Andreas and my sisters Carin and Maria with families for your dear and close friendship. 


\section{Populärvetenskaplig sammanfattning på svenska}

Bröstcancer är den vanligaste cancerformen bland svenska kvinnor med drygt 8000 nya fall varje år. Ungefär var tionde kvinna drabbas av sjukdomen under sin livstid. Den vanligaste behandlingen är operation. Den kompletteras ofta med strålning, cytostatikabehandling och andra behandlingar med läkemedel. Ungefär 8 av 10 kvinnor som får bröstcancer insjuknar i hormonkänslig bröstcancer. Det betyder att cancern använder hormonerna för sin tillväxt, framförallt östrogen. Tamoxifen är idag en etablerad tilläggsbehandling för patienter med östrogenreceptorpositiv bröstcancer. Behandlingen innebär att man tar en tablett om dagen, normalt $\mathrm{i}$ fem års tid. Tamoxifen gör att östrogenet får svårare att stimulera tumörcellen, vilket hämmar den hormonberoende tumörens tillväxt. Tamoxifen har effekt både före och efter klimakteriet, och kan ges som tilläggsbehandling efter operation för att förhindra att tumören kommer tillbaka. Den kan också ges som en profylaktisk behandling till kvinnor med hög risk att drabbas av bröstcancer.

Flera typer av cancerbehandling är förenade med biverkningar som kan påverka bland annat dödligheten i annat än cancer. Biverkningarna från tamoxifen brukar vara lindriga. De vanligaste biverkningarna är klimakteriebesvär som värmevallningar och svettningar. Allvarliga, men ovanliga biverkningar är cancer i livmodern och blodpropp. Mammografiscreening och införande av nya och bättre behandlingar har medfört att allt fler kvinnor överlever. Detta betyder att andra dödsorsaker än bröstcancer blir allt vanligare. Under 1990talet visade två skottska studier att tamoxifenbehandling tenderar att minska insjuknande och dödlighet i hjärtinfarkt. Studier har också visat att tamoxifen har positiva effekter genom att bland annat sänka nivåerna av LDL-kolesterol och C-reaktivt protein i blodet, vilka båda är riskfaktorer för hjärt- och kärlsjukdomar.

Målet med den här avhandlingen var att studera långsiktiga effekter av tamoxifenbehandlingen för hjärt- och kärlsjukdomar, samt för olika tumörsjukdomar. Mellan 1982 och 1992 lottades 4610 postmenopausala kvinnor med operabel bröstcancer till antingen två eller fem års behandling med tamoxifen. För att undersöka sjuklighet och dödlighet har tre hälsodataregister använts: Patientregistret (innehåller uppgifter om bland annat diagnoser och inläggningsdatum), cancerregistret (innehåller uppgifter om bland annat cancerdiagnoser och diagnosdatum), samt dödsorsaksregistret (innehåller uppgifter om bland annat underliggande dödsorsaker och dödsdatum). Här följer en sammanfattning av resultaten:

\section{Hjärt- och kärlsjukdomar}

Jämfört med två års tamoxifenbehandling hade de patienter som fått fem års behandling med tamoxifen en minskad risk att insjukna eller dö i ischemiska hjärtsjukdomar (kranskärlssjukdomar). Under pågående behandling var risken att insjukna i någon hjärtsjukdom reducerad. Detta gällde både ischemiska hjärtsjukdomar och andra hjärtsjukdomar, särskilt hjärtsvikt och förmaksflimmer/fladder. Efter avslutad behandling minskade risken att avlida $\mathrm{i}$ ischemiska hjärtsjukdomar. Under pågående behandling ökade 
risken att drabbas av cerebrovaskulär sjukdom, framförallt ischemisk stroke. Även efter avlutad behandling var risken att insjukna eller dö i någon cerebrovaskulär sjukdom lägre för dem som fătt tamoxifen i fem år. Riskminskningen var störst för stroke.

\section{Cancer}

Risken att insjukna i lungcancer var lägre i gruppen med fem års tamoxifen jämfört med två års tamoxifen. Denna effekt på lungcancer fanns upp till 10 år efter avslutad behandling. Risken att insjukna i endometriecancer ökade under pågående behandling, men storleken på riskökningen avtog successivt efter avslutad behandling. Risken att få en ny tumör i andra bröstet minskade i femårsgruppen, och sänkningen varade upp till 10 år efter avslutad behandling. Risken att få fjärrecidiv minskade under behandlingen och några år efter avslutad behandling. Både den totala dödligheten och bröstcancerdödligheten var reducerad bland de som fått fem års behandling med tamoxifen. Särskilt stor var reduktionen i bröstcancerdöd några år efter avslutad behandling. 


\section{References}

1. Ferlay J, Soerjomataram I, Ervik M, Dikshit R, Eser S, Mathers C, Rebelo M, Parkin DM, Forman D, Bray, F. GLOBOCAN 2012 v1.0, Cancer Incidence and Mortality Worldwide: IARC CancerBase No. 11 [Internet]. Lyon, France: International Agency for Research on Cancer; 2013. Available from: http://globocan.iarc.fr, accessed on 24/06/2014.

2. National Board of Health and Welfare. Cancer incidence in Sweden 2012. Stockholm, Sweden: National Board of Health and Welfare, 2014. (Article no. 2013-12-17). Available at: http://www.socialstyrelsen.se/Lists/Artikelkatalog/Attachments/19291/ 2013-12-17.pdf. (Accessed July 4, 2014).

3. Botha JL, Bray F, Sankila R, Parkin DM. Breast cancer incidence and mortality trends in 16 European countries. Eur J Cancer 2003;39:1718-1729.

4. Autier P, Boniol M, La Vecchia C. Disparities in breast cancer mortality trends between 30 European countries: retrospective trend analysis of WHO mortality database. BMJ 2010;341:c3620.

5. National Board of Health and Welfare. Causes of Death 2013. Stockholm, Sweden: National Board of Health and Welfare, 2014. (Article no. 2014-8-5). Available at: http://www.socialstyrelsen.se/publikationer2014/2014-8-5. (Accessed October 3, 2014).

6. Brown K. Is tamoxifen a genotoxic carcinogen in women? Mutagenesis 2009;24:391-404.

7. Jordan VC. Fourteenth Gaddum Memorial Lecture. A current view of tamoxifen for the treatment and prevention of breast cancer. Br J Pharmacol 1993;110:507-517.

8. Swedish Breast Cancer Cooperative Group. Randomized trial of two versus five years of adjuvant tamoxifen for postmenopausal early stage breast cancer. J Natl Cancer Inst 1996; 88:1543-1549.

9. Early Breast Cancer Trialists' Collaborative Group. Effects of chemotherapy and hormonal therapy for early breast cancer on recurrence and 15-year survival: an overview of the randomised trials. Lancet 2005;365:1687-1717.

10. Early Breast Cancer Trialists' Collaborative Group. Tamoxifen for early breast cancer: an overview of the randomised trials. Lancet 1998;351:1451-1467.

11. Love RR, Cameron L, Connell BL, Leventhal H. Symptoms associated with tamoxifen treatment in postmenopausal women. Arch Intern Med 1991;151:18421847. 
12. Day R, Ganz PA, Costantino JP, Cronin WM, Wickerham DL, Fisher B. Healthrelated quality of life and tamoxifen in breast cancer prevention: a report from the National Surgical Adjuvant Breast and Bowel Project P-1 Study. J Clin Oncol 1999; 17:2659-2669.

13. Fisher B, Costantino JP, Wickerham DL et al. Tamoxifen for the prevention of breast cancer: current status of the national surgical adjuvant breast and bowel project P-1 study. J Natl Cancer Inst 2005;97:1652-1662.

14. Rössner S, Wallgren A. Serum lipoproteins and proteins after breast cancer surgery and effects of tamoxifen. Atherosclerosis 1984;52:339-346.

15. Cushman M, Costantino JP, Tracy RP, Song K, Buckley L, Roberts JD et al. Tamoxifen and cardiac risk factors in healthy women: suggestion of an anti-inflammatory effect. Arterioscler Thromb Vasc Biol 2001;21:255-261.

16. Gupta S, Tandon VR, Kapoor B, Gupta A, Gupta GD, Khajuria V. Effects of tamoxifen therapy on plasma lipid profile in patients of breast cancer. J Assoc Physicians India 2006;54:183-186.

17. Powles TJ, Tillyer CR, Jones AL et al. Prevention of breast cancer with tamoxifen - an update on the Royal Marsden Hospital Pilot Programme. Eur J Cancer 1990;26:680-684.

18. Ridker PM, Rifai N, Rose L, Buring JE, Cook NR. Comparison of c-reactive protein and low-density lipoprotein cholesterol levels in the prediction of first cardiovascular events. N Engl J Med 2002;347:1557-1565.

19. McDonald CC, Alexander FE, Whyte BW, Forrest AP, Stewart HJ. Cardiac and vascular morbidity in women receiving adjuvant tamoxifen for breast cancer in a randomized trial. BMJ 1995;311:977-980.

20. Rutqvist LE, Mattsson A. Cardiac and thromboembolic morbidity among postmenopausal women with early-stage breast cancer in a randomized trial of adjuvant tamoxifen. The Stockholm Breast Cancer Study Group. J Natl Cancer Inst 1993;85:1398-1406.

21. Cuzick J, Forbes JF, Sestak I, Cawthorn S, Hamed H, Holli K et al. Long-term results of tamoxifen prophylaxis for breast cancer--96-month follow-up of the randomized IBIS-I trial. J Natl Cancer Inst 2007;99:272-282.

22. Braithwaite RS, Chlebowski RT, Lau J, George S, Hess R, Col NF. Meta-analysis of vascular and neoplastic events associated with tamoxifen. J Gen Intern Med 2003;18:937947. 
23. Bushnell CD, Goldstein LB. Risk of ischemic stroke with tamoxifen treatment for breast cancer: a meta-analysis. Neurology 2004;63:1230-1233.

24. National Board of Health and Welfare. Inpatients diseases in Sweden 1987-2012. Stockholm, Sweden: National Board of Health and Welfare, 2013. (Article no. 2013-1227). Available at: http://www.socialstyrelsen.se/Lists/Artikelkatalog/Attachments/ 19302/2013-12-27.pdf. (Accessed July 4, 2014).

25. National Board of Health and Welfare. Causes of Death 2012. Stockholm, Sweden: National Board of Health and Welfare, 2013. (Article no. 2013-8-6). Available at: http://www.socialstyrelsen.se/Lists/Artikelkatalog/Attachments/19175/2013-8-6.pdf. (Accessed July 4, 2014).

26. National Board of Health and Welfare. Swedish Cancer Registry. Available at: http://www.socialstyrelsen.se/register/halsodataregister/cancerregistret/inenglish. (Accessed July 4, 2014).

27. Kirkwood BR, Sterne JAC. Essential medical statistics, $2^{\text {nd }}$ ed. Oxford: Blackwell Science, 2003.

28. McDonald CC, Stewart HJ. Fatal myocardial infarction in the Scottish adjuvant tamoxifen trial. BMJ 1991;303:435-437.

29. Costantino JP, Kuller LH, Ives DG, Fisher B, Dignam J. Coronary heart disease mortality and adjuvant tamoxifen therapy. J Natl Cancer Inst 1997;89:776-782.

30. Teerlink JR, Goldhaber SZ, Pfeffer MA. An overview of contemporary etiologies of congestive heart failure. Am Heart J 1991;121:1852-1853.

31. Fox KF, Cowie MR, Wood DA et al. Coronary artery disease as the cause of incident heart failure in the population. Eur Heart Journal 2001;22:228-236.

32. Kannel WB, Abbot RD. Incidence and prognosis of unrecognized myocardial infarction. An update on the Framingham Study. N Engl J Med 1984;311:1144-1147.

33. Kannel WB. Silent myocardial ischemia and infarction: insights from the Framingham Study. Cardiology Clinics 1986;4:583-591.

34. Kardys I, Knetsch AM, Bleumink GS et al. C-reactive protein and risk of heart failure. The Rotterdam Study. Am Heart J 2006;152:514-520.

35. Vasan RS, Sullivan LM, Roubenoff R et al. Inflammatory markers and risk of heart failure in eldery subjects without prior myocardial infarction: The Framingham Heart Study. Circulation 2003;107:1486-1491. 
36. Williams ES, Shah SJ, Ali S, Na BY, Schiller NB, Whooley MA. C-reactive protein, diastolic dysfunction, and risk of heart failure in patients with coronary heart disease: Heart and Soul Study. Eur J Heart Fail 2008;10:63-69.

37. Benjamin EJ, Levy D, Vaziri SM, D'Agostino RB, Belanger AJ, Wolf PA. Independent risk factors for atrial fibrillation in a population-based cohort. The Framingham Heart Study. JAMA 1994;271:840-844.

38. Nelson HD, Fu R, Griffin JC, Nygren P, Smith ME, Humphrey L. Systematic review: comparative effectiveness of medications to reduce risk for primary breast cancer. Ann Intern Med 2009;151:703-715.

39. Lother SA, Harding GA, Musto G, Navaratnam S, Pitz MW. Antiestrogen use and survival of women with non-small cell lung cancer in Manitoba, Canada. Horm Cancer 2013;4:270-276.

40. Bouchardy C, Benhamou S, Schaffar R. Lung cancer mortality risk among breast cancer patients treated with anti-estrogens. Cancer 2011;117:1288-1295.

41. Baik CS, Eaton KD. Estrogen signaling in lung cancer: an opportunity for novel therapy. Cancers 2012;4:969-988.

42. Warner M, Gustafsson JA. The role of estrogen receptor beta (ERbeta) in malignant diseases--a new potential target for antiproliferative drugs in prevention and treatment of cancer. Biochem Biophys Res Commun 2010;396:63-66.

43. Shiels MS, Pfeiffer RM, Hildesheim A. Circulating inflammation markers and prospective risk for lung cancer. J Natl Cancer Inst 2013;105:1871-1880.

44. Allin KH, Nordestgaard BG. Elevated C-reactive protein in the diagnosis, prognosis, and cause of cancer. Crit Rev Clin Lab Sci 2011;48:155-170.

45. Cuzick J, Sestak I, Bonanni B et al. Selective oestrogen receptor modulators in prevention of breast cancer: an updated meta-analysis of individual participant data. Lancet 2013; 381: $1827-1834$.

46. Bertelsen L, Bernstein L, Olsen JH et al. Effect of systemic adjuvant treatment on risk for contralateral breast cancer in the Women's Environment, Cancer and Radiation Epidemiology Study. J Natl Cancer Inst 2008;100:32-40.

47. Alkner S, Bendahl PO, Fernö M, Nordenskjöld B, Rydén L. Tamoxifen reduces the risk of contralateral breast cancer in premenopausal women: Results from a controlled randomised trial. Eur J Cancer 2009;45:2496-2502. 
48. Mattsson B, Rutqvist LE, Wallgren A. Undernotification of diagnosed cancer cases to the Stockholm Cancer Registry. Int J Epidemiol 1985;14:64-69.

49. Barlow L, Westergren K, Holmberg L, Talbäck M. The completeness of the Swedish Cancer Register - a sample survey for year 1998. Acta Oncologica 2009;48:27-33.

50. Ludvigsson JF, Andersson E, Ekbom A, Feychting M, Kim JL, Reuterwall C et al. External review and validation of the Swedish national inpatient register. BMC Public Health 2011;11:450.

51. Nilsson AC, Spetz CL, Carsjö K, Nightingale R, Smedby B. Reliability of the hospital registry. The diagnostic data are better than their reputation. Läkartidningen 1994;91:598, 603-605. In Swedish.

52. National Board of Health and Welfare. Dödsorsaksstatistik. Historik, produktionsmetoder och tillförlitlighet. (In Swedish). Stockholm, Sweden: National Board of Health and Welfare, 2010. (Article no. 2010-4-33). Available at: http://www.socialstyrelsen.se/Lists/Artikelkatalog/Attachments/18019/2010-4-33.pdf (Accessed Oct 24, 2014).

53. Johansson LA, Björkenstam C, Westerling R. Unexplained differences between hospital and mortality data indicated mistakes in death certification: an investigation of 1,094 deaths in Sweden during 1995. J Clin Epidemiol 2009;62:12021209. 



\section{Papers}

The articles associated with this thesis have been removed for copyright reasons. For more details about these see:

http://urn.kb.se/resolve?urn=urn:nbn:se:liu:diva- 112085 